\title{
Anadolu'daki Geleneksel Türk Evlerinin Plan, Cephe ve Süsleme Özellikleri Bağlamında İncelenmesi
}

\author{
Arş. Gör. Gökhan UŞMA \\ Adana Alparslan Türkeş Bilim ve Teknoloji Üniversitesi \\ Mimarlık ve Tasarım Fakültesi, Mimarlık Bölümü \\ usmagokhan@gmail.com \\ ORCID: 0000-0002-7293-123X
}

\begin{abstract}
Öz
Geleneksel Türk evlerinin mimari nitelikleri, tarih boyunca devam eden, eklemlenen bir kültür birikimiyle, coğrafi ve iklimsel özelliklerin etkisiyle ayrıca bölgenin sahip olduğu sosyo-ekonomik özellikler, inanç, yaşam biçimi gibi etmenlerle ortaya çıkmıştır. Tüm bu bahsi geçen unsurların bir araya gelmesiyle tarihsel süreçte gelişimine devam eden geleneksel Türk evlerinin plan, cephe ve süsleme özelliklerinin daha zengin bir niteliğe kavuştuğu söylenebilir. Bu çalışmanın amacı da Anadolu'daki geleneksel Türk evlerini; plan, cephe ve süsleme özellikleri çerçevesinde ele almak ve bütüncül bir bakış sağlamaktır. Bu kapsamda çalışma yöntemi olarak geniş bir literatür taraması yapılmıştır. Çalışma süreci üç aşamadan oluşmaktadır. Birinci aşamada, geleneksel Türk evlerinin ana ögeleri, mekân kurgusu ve plan özellikleri üzerine yapılan çalışmalar incelenmiş ve plan şemaları çizilerek örneklerle ifade edilmiştir. İkinci aşamada, cephe özellikleri üzerine yapılan çalışmalar değerlendirilmiş ve cepheyi oluşturan önemli ögeler sırasıyla ele alınmışıı. Üçüncü aşamada, süsleme özellikleri üzerine araştırmalar gerçekleştirilmiş ve dönemsel olarak yaygın kullanım gösteren süslemeler, kronolojik bir şekilde aktarımıştır. Bütüncül bir bakış açısıyla gerçekleştirilen bu araştırmanın, yerel mimari ve geleneksel konutlar üzerine yapılacak çalışmalara katkı sağlayacağı düşünülmektedir.
\end{abstract}

Anahtar Kelimeler: geleneksel türk evleri, plan, cephe, süsleme, anadolu Artuklu Sanat ve Beşeri Bilimler Dergisi, 6, 227-259. 


\title{
An Examination of Traditional Turkish Houses in Anatolia in the Context of Plan, Façade and Decorative Features
}

\begin{abstract}
The architectural characteristics of traditional Turkish houses have emerged with a cultural accumulation that continues and articulates throughout history. The geographical and climatic features of the lands in which it is settled have also been factors that have influenced the architecture of traditional Turkish houses in every period. Situations where geographical and climatic characteristics are effective; can be listed as construction technique, application methods, material selection and facade formation. In addition to these, it is seen that different architectural consequences occur in settlements with different characteristics, together with factors such as the beliefs that are effective in the region, the economic situation, the lifestyle of the local people. It can be said that the plan, facade and decoration features of traditional Turkish houses have gained a richer quality with the combination of all these mentioned elements. The aim of this study is to consider traditional Turkish houses within the framework of their plan, façade and decoration features and to provide a holistic view. In this context, a wide literature review has been made. It is thought that this research, carried out with a holistic perspective, will contribute to the studies on vernacular architecture and traditional houses.
\end{abstract}

Keywords: traditional turkish houses, plan, facade, decoration, anatolia 


\section{arts}

\section{Gíiş̧}

Sedad Hakkı Eldem'in tanımına göre, "Türk Evi eski Osmanlı devletinin işgal ettiği sınırlar içinde, eski tabirleriyle Rumeli ve Anadolu mıntıkalarında yerleşmiş, gelişmiş ve 500 sene kadar tutunmuş kendi özellikleriyle oluşmuş bir ev tipidir." Yerleştiği topraklarda 15. ve 16. yüzyıldan itibaren diğer ev tiplerinin yerini almaya başlamıştır. 17. ve 18. yüzyıllar ise Türk evinin en çok yayılma gösterdiği dönemler olmuştur (Eldem, 1954, s. 11). Geleneksel Türk evlerinin mimari nitelikleri, tarih boyunca devam eden ve eklemlenen bir kültür birikimiyle ortaya çıkmıştır. Anadolu'nun coğrafi ve iklimsel özellikleri de geleneksel Türk evlerinin mimarisine her dönemde etki eden unsurlar olmuştur. Bunların yanı sıra, bölgede etkili olan inançlar, ekonomik durum, yöre halkının yaşam biçimi gibi unsurlarla birlikte farklı özelliklere sahip yerleşim yerlerinde mimari bağlamda farklı sonuçların ortaya çıktığı görülmektedir. Tüm bu bahsi geçen unsurların bir araya gelmesiyle tarihsel süreçte gelişimine devam eden geleneksel Türk evlerinin plan, cephe ve süsleme özelliklerinin daha zengin bir niteliğe kavuştuğu söylenebilir.

Literatürde konu ile ilgili yer alan çalışmaların çoğunlukla plan özellikleri veya geleneksel Türk evlerinin belirli özellikleri üzerinde yoğunlaşılan çalışmalar olduğu görülmektedir. Bu nedenle geleneksel Türk evlerinin mimari özelliklerinin net bir şekilde anlaşllabilmesi ve okunabilmesi için, ana bileşenler olan plan, cephe ve süsleme özelliklerinin bir arada ele alınması intiyacı doğmaktadır. Bu çalışmanın amacı da Anadolu'daki geleneksel Türk evlerini; plan, cephe ve süsleme özellikleri çerçevesinde ele almak ve ana bileşenlerin bir arada ele alınmasıyla bahsi geçen bütüncül bakışı sağlayabilmektir. Ayrıca farklı araştırmalardan elde edilen farklı görüşler ve çalışmalardan yararlanılarak daha kapsamlı bir çalışmayla sunuımasının da literatüre katkı sağlayacağı düşünülmektedir. Bu kapsamda çalışma yöntemi olarak geniş bir literatür taraması yapılmıştır. Süreç; plan, cephe ve süsleme özelliklerinin ele alındığı üç aşamadan meydana gelmektedir. Çalışmanın birinci bölümünde geleneksel Türk evlerinin ana mekanları/ögeleri yer almakta ve mekân kurgusundan bahsedilmektedir. İkinci bölümde, geleneksel Türk evlerinin plan tipleri ve özellikleri detaylı olarak değerlendirilmiştir. Üçüncü bölümde, cephe özellikleri incelenmiş ve cepheyi oluşturan önemli ögeler sırasıyla ele alınmıştır. Dördüncü bölümde ise, süsleme özelliklerinin daha önce literatürde yer almayan bir şekilde "kronolojik olarak" aktarıması yer almaktadır. 


\section{Geleneksel Türk Evlerinin Ana Mekanları/Ögeleri}

Anadolu' daki geleneksel Türk evlerinin ana mekanları/ögeleri ve aralarındaki ilişki konutların özgün niteliklerinin oluşmasında büyük öneme sahiptir. Geleneksel Türk evlerinde yaşama birimleri olan odalar arasındaki bağlantıyı sofa sağlar. Geleneksel Türk evini oluş̧uran temel ögelerden biri olan sofa, "Sergâhsergi, seyvan, çardak, divanhane, hayat" gibi isimler de almışıı. Sofanın geleneksel Türk evi kuruluş düzeninin oluşumundaki rolü oldukça fazladır. lilk örneklerde sofaya çok az rastlanmaktadır. Sofanın oluşumundan önce, odalar çadırların kullanım özelliklerini taşımaktaydı. Sonrasında odalar arasında ortak mekân kurulmuştur (Eldem, 1954, s. 16-17).

Sofanın bir diğer işlevi de toplanma mekârmlmasıdır. Toplanma bölümü haricindeki diğer bölümler oturmak için kullanılmıştır. Sofa aynı zamanda düğün, nişan, cenaze gibi törenler için de kullanıma uygun bir mekandır. Sofanın bir veya birkaç tarafı kapalı olabilir ve sofa aynı zamanda tam ortada da yer alabilir. Sofanın manzaraya bakan, elverişli taraflarında köşk, eyvan, taht ve sekilik gibi döşemeden biraz yükseltilmiş bölümler bulunur. Bu bölümler dinlenme ve seyir alanları olarak kullanıır (Görsel 1). Eyvanlar; dışardan gelecek etkilere karşı biraz daha korunakkı düzenlenen yerlerdir. Dar tarafı sofaya bakacak şekilde genellikle iki oda arasında bulunan mekanlardır (Görsel 2). Sofanın ortası orta eyvan, yanları ise yan eyvan olarak adlandırıır. Köşkler ise fazlaca aydınlık, bol pencereli mekanlardır (Görsel 3). Bazılarında fıskiyeli havuzlar bile yer almaktadır. Taht ve sekilik iki ya da üç tarafı açık, döşemeden birkaç basamak yükseltilmiş, bazı durumlarda konsolun taşıdığı eklenti mekanlardır (Görsel 4) (Sözen ve Eruzun, 1992, s. 146-152).

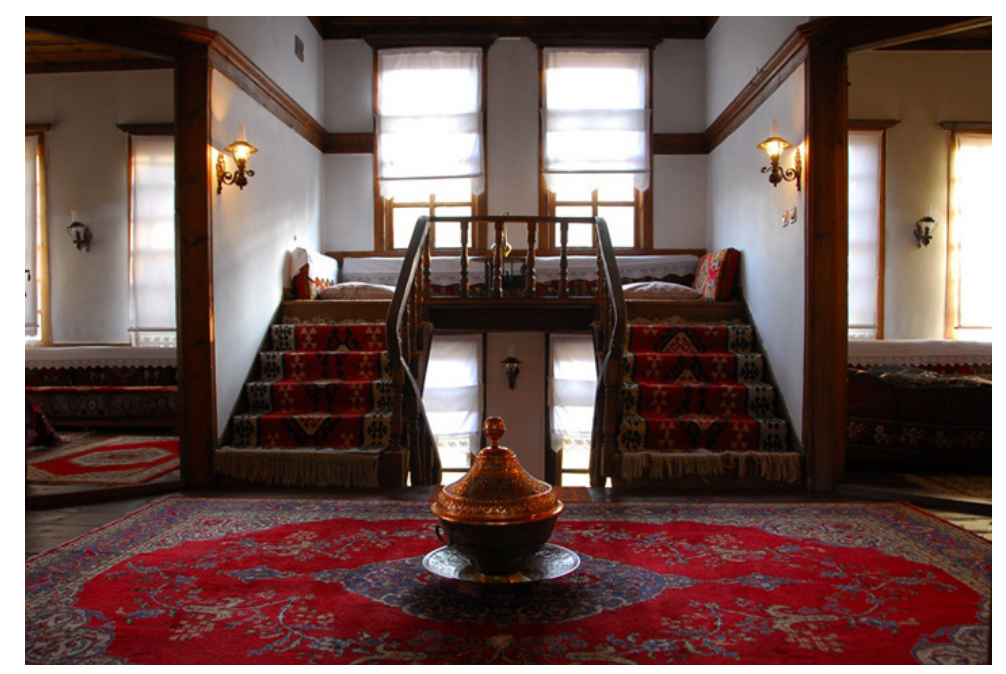

Görsel 1. Geleneksel Türk evinde sofa (Binay, 2021). 


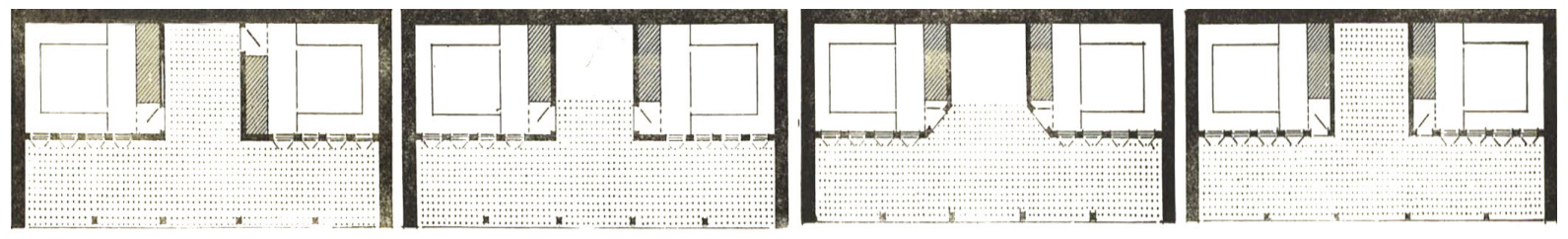

Görsel 2. Geleneksel Türk evinde sofa, oda ve eyvan ilişkisi (Eldem, 1954, s. 17-18)

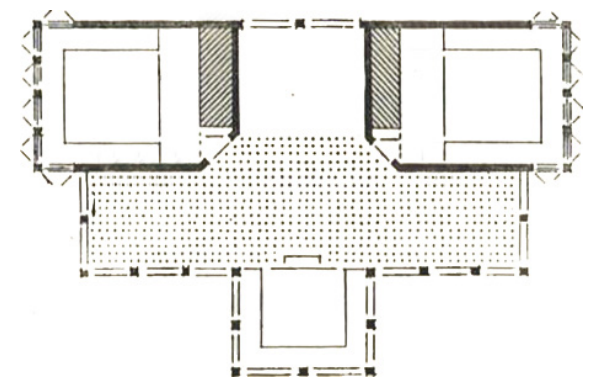

Görsel 3. Geleneksel Türk evinde köşk (Eldem, 1954, s. 19)

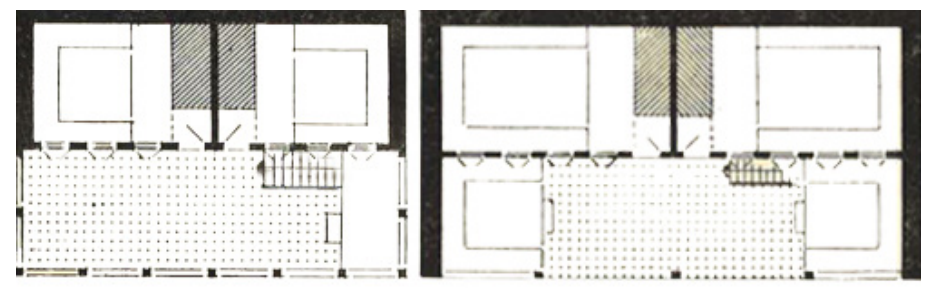

Görsel 4. Geleneksel Türk evinde taht (Eldem, 1954, s. 19)

Sofa, erken dönem evlerde açıktır. Tavan, ahşap dikmeler üzerinde yükseltilmiştir. Sonraki dönemlerde iklim ve çevre koşullarından korunmak amacıyla çeşitli eklentiler ile daha korunaklı bir hale getirilmiştir. Bu eklentilerin sonunda camekanlarla tamamen kapatılmıştır. Fakat bu değişim ve düzenlemeler plan tipini ve sofanın odalar arasındaki ortak mekân olma özelliğini değiştirmemiştir (Eldem, 1984, s. 18; Küçükerman, 1985, s. 53).

Turgut Cansever'in deyişiyle "Türk evinin temel mimari birimi olan 'oda', hem kelime kökeni olarak hem de nitelikleriyle göçebe çadırı olan 'otağ'ın bir devamıdır". Bu benzerlik, ikisinin de benzer fonksiyonlara hizmet etmesi, çok amaçlı kullanıma uygun olarak tasarlanmasına dayanır (Cansever, 2002, s. 313). Fakat olumsuz iklim şartlarında, çadıın taşınabilirliğinin yanında odanın da bu şartlara uyum sağlayabilecek şekilde oluşturulması gerekmektedir. Bu nedenle oda, çevrenin ve hayatın değişkenlerine uyum sağlayarak farklı kullanış biçimlerine olanak 
tanıyabilecek nitelikte olmalıdır. Odanın çok amaçlı kullanıma olanak sağlaması en önemli özelliklerinden biridir. Hareketli elemanların kullanılabilmesi, yatakların kullanıldıktan sonra dolaplara kaldırılabilmesi, sedirin oturmak, uzanmak ve yatmak için kullanılabilmesi gibi durumlar odanın esnek kullanım özelliğinin örnekleridir (Ateş, 2008, s. 21; Cansever, 2002, s. 313-318; Sözen ve Eruzun, 1992, s. 67-70).

Geleneksel Türk evinde her odanın bir hizmet alanı bulunur. Bu alan genellikle sofa olmakla birlikte başka bir mekân da olabilir. Bu iki ögenin belirli bir çoğalma düzeni içinde gelişmesi ve biçimlenmesiyle Türk Evinin kuruluş düzeni oluşmuştur (Görsel 5).
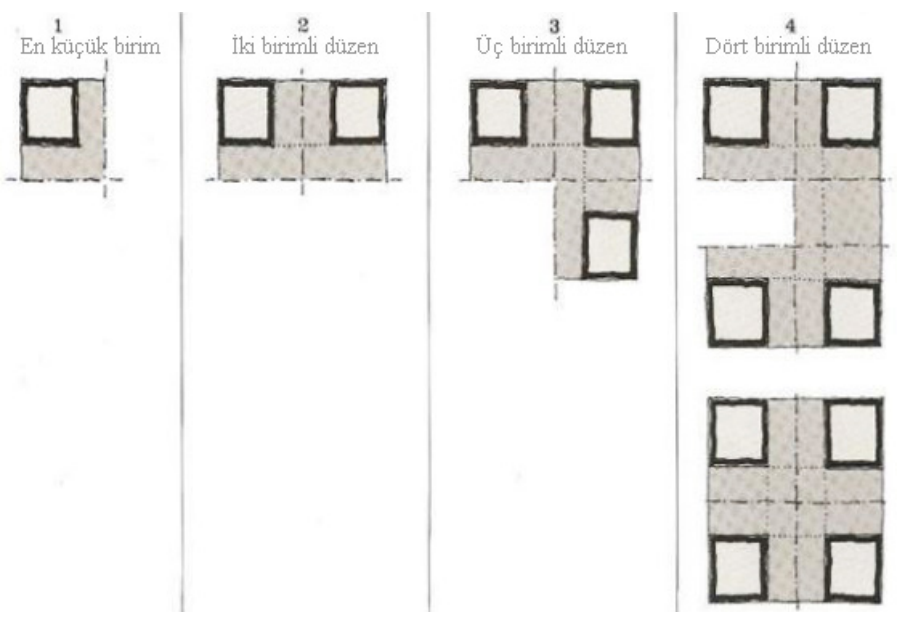

Görsel 5. Anadolu'daki geleneksel Türk evlerinin oluşum düzeni (Küçükerman, 1985, s. 66)

Geleneksel Türk evinde genellikle kapı odaya direkt olarak açılmaz. Kapı açılınca önce yaşmak duvarı görünür (Görsel 6) (Bektaş, 1996, s. 106). Bu süre içinde içerde oturan kişiler toparlanmış olur. Odaya alçaltılmış bir dolaşım alanından (Seki altı) sonra ulaşıı. Seki altının bir tarafı oda iken diğer tarafı farklı amaçlar için kullanılan bölmelere ayrımış olan dolaptır. Dolaplarda yatakların konulduğu yüklük, lambalık, fincanlık, açık raflar ve başka amaçlarla kullanılan kapalı dolaplar bulunur (Görsel 7). Ayrıca yunmalık (gusülhane) olarak adlandırılan küçük banyolar da bu dolap kapaklarının arkasında yer alır.
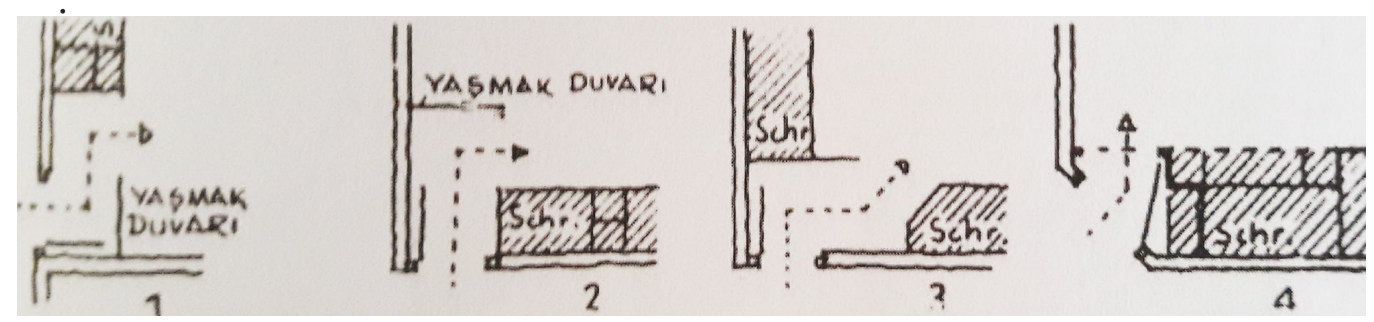

Görsel 6. Odaya giriş şekilleri ve yaşmak duvarı kullanımı (Bektaş, 1996, s. 106) 


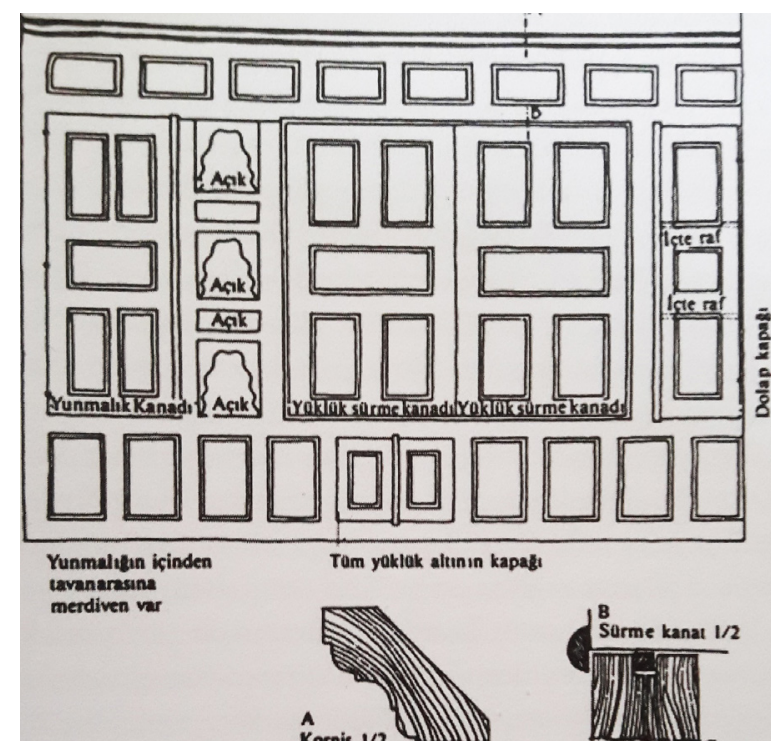

Görsel 7. Yüklük duvarı (Cahit Mehmet Ali Evi) (Bektaş, 1996, s. 108)

Oda (seki), seki altından bir basamak yukarıda yer alır. Bu iki mekânın tırabzanla ayrıldığı durumlar da mevcuttur (Görsel 8). Pencere altlarında oturma alanı olan sedir yer almaktadır. Odanın bir veya daha fazla duvarında dolap, bir duvarında da ısınma, havalandırma ve pişirme işi için ocak yer almaktadır (Görsel 9). Ocağın sürme bir kapakla kapatılabilenleri de vardır. Bazı durumlarda ocaklar sahip olduğu biçim ve süslemeyle odada kimliğiyle ağır basan bir öge olabilmektedir (Görsel 10) (Bektaş, 1996, s. 106-112; Eldem, 1987, s. 78-90; Küçükerman, 1985, s. 173-178)

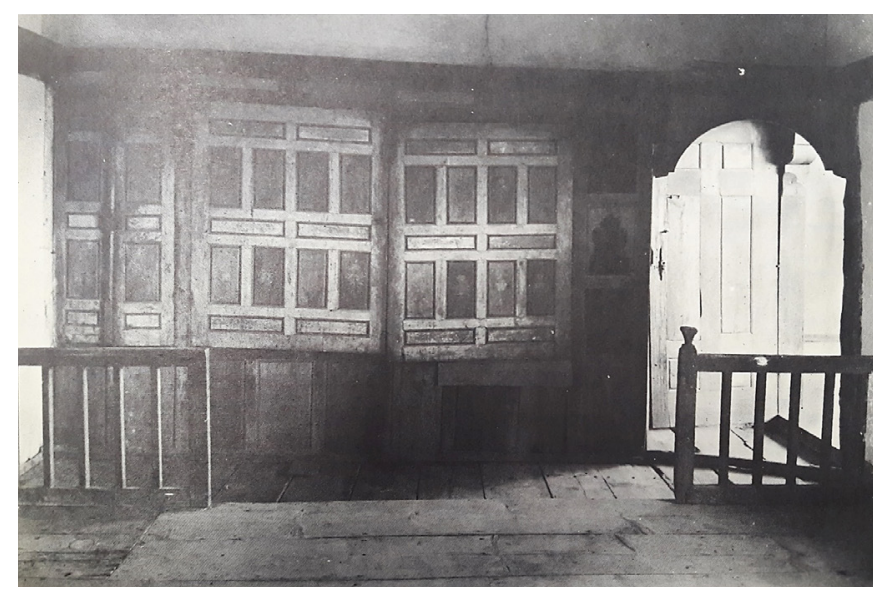

Görsel 8. Seki altı ve sekinin tırabzanla ayrlışı (Hisar, Bursa) (Eldem, 1987, s. 25) 


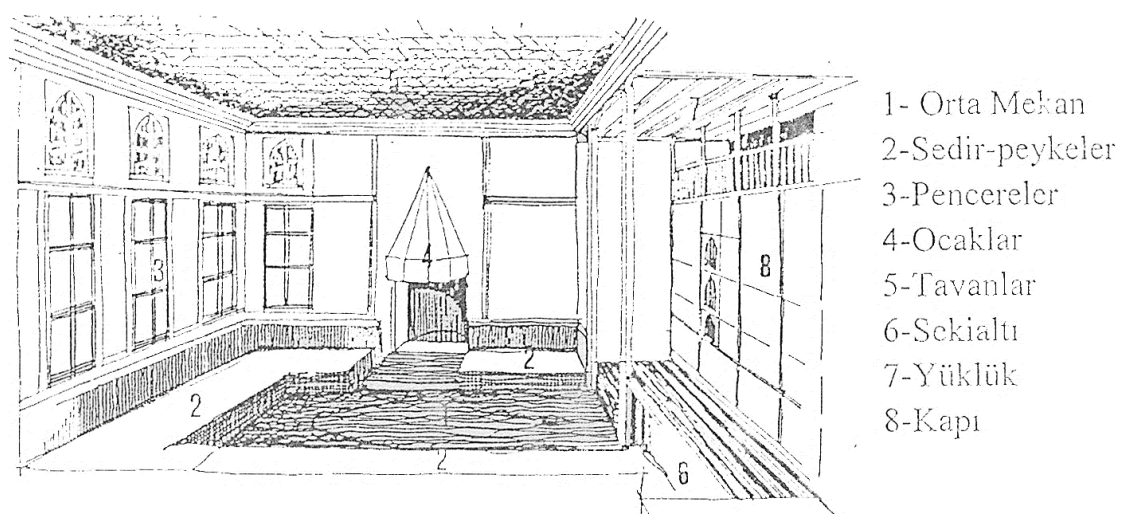

Görsel 9. Geleneksel Türk evinde oda düzeni (Pilehvarian, s. 70)

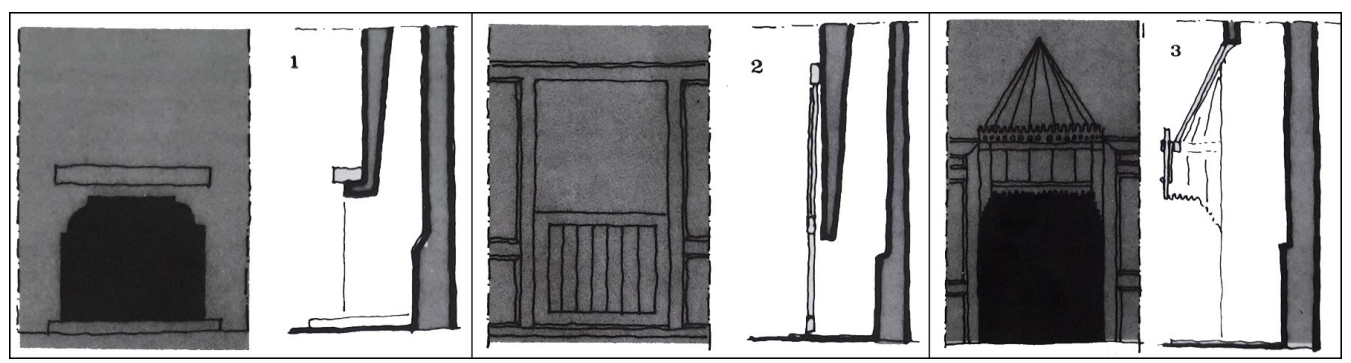

Görsel 10. Geleneksel Türk evinde görülen ocak tipleri: 1- kapak veya davlumbazın olmadığı en basit tip 2- kapaklı ocak tipi 3- en gelişmiş tip (Küçükerman, 1985, s. 182)

Odanın duvarlarında ortalama 200 cm yükseklikte dolaşan raf, sergen olarak adlandırılır. Sergenin üstünde meyveler, çini veya bakır kaplar dizili olur. Sergenin altında yer alan, sokağa ya da hayata bakan büyük pencereler, yaklaşık olarak bire iki oranındadırlar. Ölçüleri insan ölçüsü baz alınarak, kullanım olanaklarına göre ayarlanmıştır. Hem oturma hem de ayakta durma durumları göz önünde bulundurulmuş, göz hizasında yerleştirilmişlerdir. Genellikle giyotin olmakla beraber (Görsel 11), 19. yüzyıl başlarına kadar iki katı olarak yapılmışlardır. Üst tarafı sabit, alt tarafı ise açlır kapanır özelliktedir. (Kuban, 1995, s. 122-124). Sergenin üzerinde ise renkli camlarıla tepe pencereleri yer alır. Tepe pencerelerinin renkli camları sayesinde her oda kendine özgü bir ışığa sahip olur (Görsel 12).

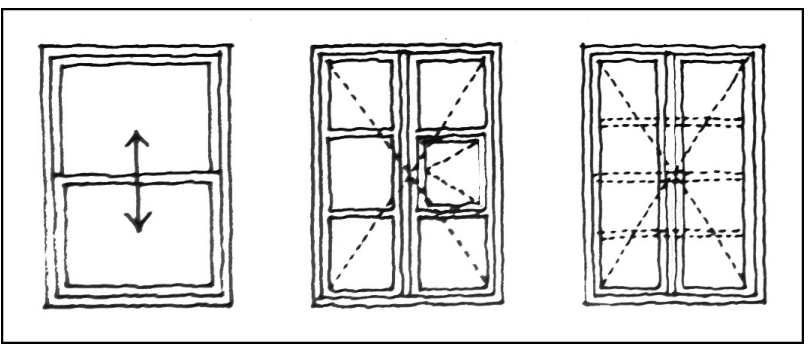

Görsel 11. Geleneksel Türk evindeki pencere açıllş yönleri (Küçükerman, 1985, s. 118) 

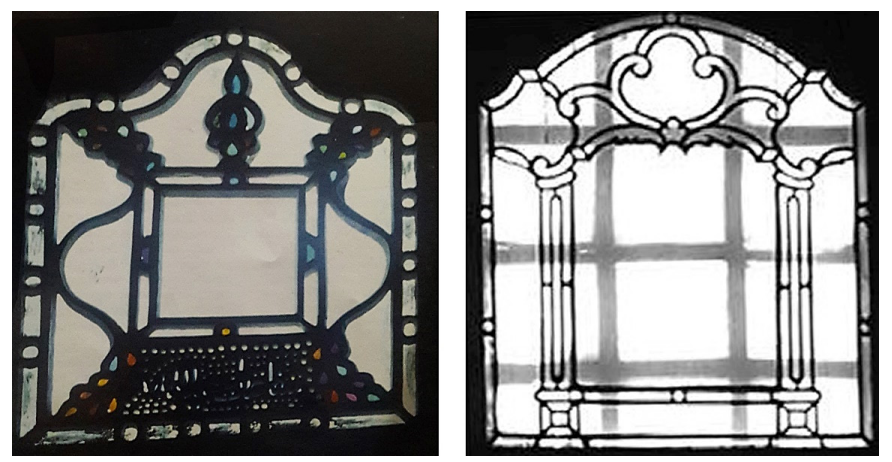

Görsel 12. Geleneksel Türk evinde tepe pencereleri: 1. Safranbolu (Küçükerman, 1985, s. 124); 2. Kavafyan Konağı, ìstanbul (Öztek, 2014)

Geleneksel Türk evinde evin giriş kapıları daima büyük ve çoğunlukla iki kanatıdır. Bahçe içinde kalanların çoğunda saçak kullanılmıştır. Kanatlar som ya da aynalıdır. Kapı evin sembolü durumundadır. Oda kapıları ise sofaya açılır ve her odanın sadece bir kapısı bulunur. Oda kapılarında kapı kanadı daha küçük ve tektir (Eldem, 1987, s. 80). Kapı kanadının odanın içine bakan tarafı daha özenli ve süslü iken dış tarafı daha sadedir. Odaya girişte kapı ve dolabın ilişkisinden dolayı bu mimari ögeler birlikte çözümlenmişlerdir (Görsel 13).
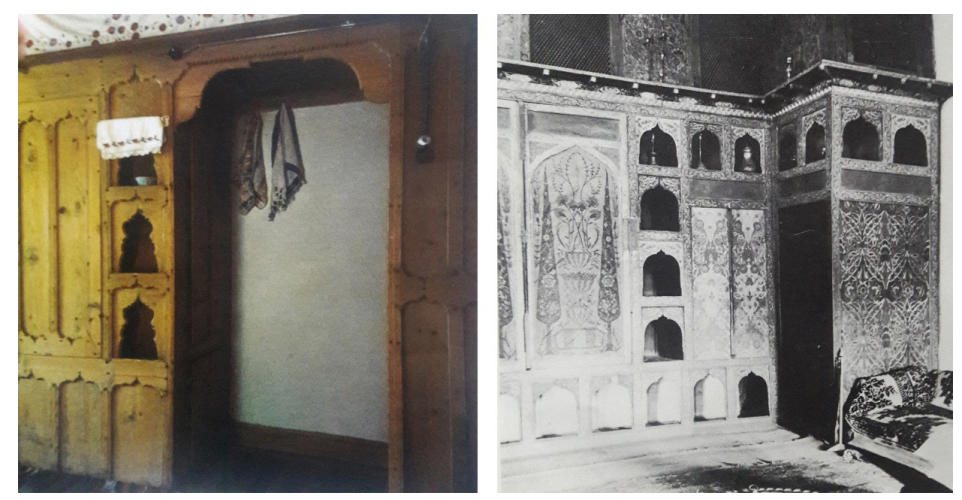

Görsel 13. Geleneksel Türk evinde odaya giriş, kapı ve dolap ilişkisi (Küçükerman, 1985, s. 130, 133)

Tavanlar ahşap kaplanmış ve çıtalarla, çeşitli motiflerle bezenmiştir. Kurulumu evler ve odalarda farklı şekillerde olmuştur (Bektaş, 1996, s. 56). Çoğunlukla tavanların şekillendirilmesive süslemesi ev sahibininstatüsü ve bütçe durumuna bağlıdır. Odaların genelde kare şeklinde olduğu görülür. Ancak bazı durumlarda evin oturduğu arazi ve doğanın etkisi ile dik açıya sahip olmayan odalar yapılmıştır. Bu odaların büyük kısmında bile tavanın kare olması için bir çözüm bulunmuştur. Yapılar ve odalarda 
üst örtü kullanılan alanın önemine göre farklı biçimlendirilmiştir. Daha yalın odaların tavanları bir işlem yapılmadan bırakılmıştır. Daha özel odalar için tavan kirişlemesinin kaplanarak farklı şekillerde oluşturulduğu görülür. Zaman içerisinde fonksiyonel üs† örtüye yapılan farklı uygulamalar görsel bir duruma ve süslemeye dönüşmüştür. Bu durumun kentlerde daha çok geliştirilip yaygın hale geldiği görülmektedir. Üsø̈rtüye zaman içerisinde farklı işlevler yüklenmiştir. Bunun en güzel örneği ise Trabzon ve Rize arasında bulunan bir evdir (Küçükerman, 1985, s. 158). Evde baş odanın tavanına, odanın daha iyi havalandırıması amaçlı bir havalandırma sistemi yapılmıştır. Tavan kaplaması, farklı yüksekliklere sahip katmanlardan oluşturulmuş ve bu katmanlar arasındaki boşluklardan hava transferi sağlayabilecek şekilde kurulmuştur (Görsel 14)

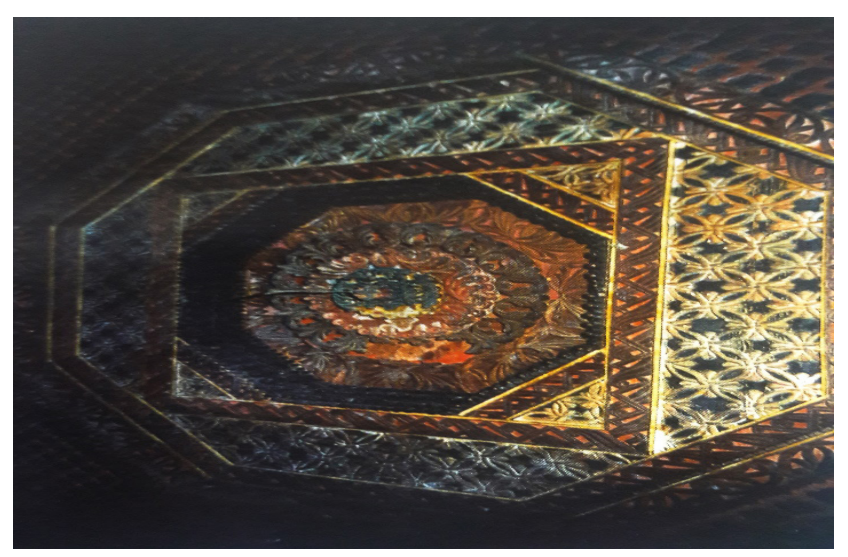

Görsel 14. Geleneksel Türk evinde havalandırma düzenine sahip tavan örneği (Küçükerman, 1985, s. 162)

Geleneksel Türk evinin sokakla ve kent yaşamıyla doğrudan ilişki kurabilmesi çıkmalar sayesinde sağlanmıştır (Görsel 15) (Cerasi, 1999, s. 155-156). Çıkmalarda açılan pencerelerin yeri de önemlidir. Sokakların dar olması sebebiyle karşı eve direkł olarak bakan çıkma cephesi yerine sokağı derinlemesine gören cepheye pencereler açılmıştır. Pencereler dışarıdan görünümüne göre değil içerinin algılaması ve ihtiyaçlarına göre açılmıştır. Burada da geleneksel Türk evinin çözümünde iç kurgunun öncelikli olduğu, çözümün içten başladığı anlaşımaktadır (Bektaş, 1996, s. 24-33). Cumbanın kent ve sokak dokusundaki yeri ve önemini Le Corbusier, "işłe büyük abidelerin yer aldığı sırtlardan aşağı doğru az meyilli, çatıların gölgeleri altındaki cumbalar ve bunların gölgeleri ile oluşan mor, gölgeli satıhların pencerelerin geometrisiyle, aradaki bahçelerin yeşillikleriyle meydana getirdiği adeta denize kadar uzanmış muhteşem bir acem halısını hatırlatıyordu." diyerek ifade etmiştir (Cansever, 2010, s. 138). 

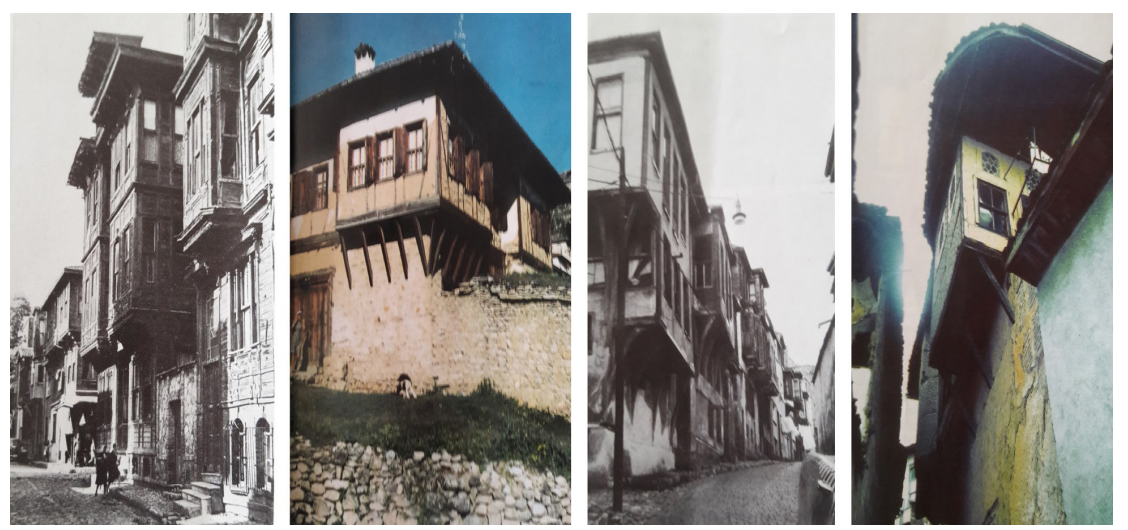

Görsel 15. Geleneksel Türk evinde çıkma ve sokak ilişkisi (Küçükerman, 1985, s. 27, 15, 119)

Genellikle iki oda arasındaki bağlantıyı sağlayan geçitler, odalarda bulunan dolapların bir bölümü gibi düzenlenmiş ve gizli tutulmak istenmiştir. Ụ̧̈ danın birbirine bağlanılması istenilen durumlarda ise ortada yer alan odanın yüklük bölmelerinin arkası geçit olarak düzenlenmiştir (Görsel 16). Zamanla bu geçitlerin plandaki görünürlüğü artmış ve koridorlar oluşmuştur (Eldem, 1954, s. 20).
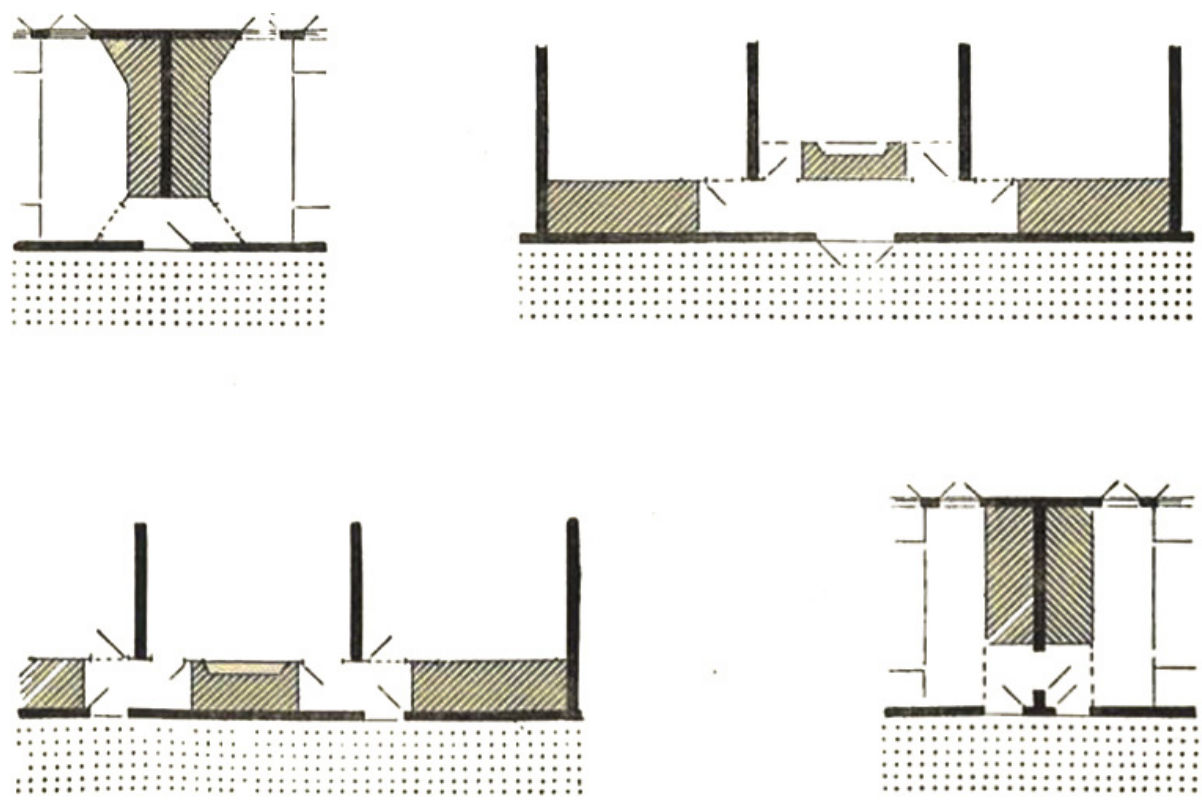

Görsel 16. Odalar arasındaki geçitler (Eldem, 1954, s. 20)

Merdivenler geleneksel Türk evinde sofanın içinde yer aldıkları zaman plan içinde çok önem arz etmemekle birlikte, sofanın dışında kendilerine özel bir yerde oldukları zaman planda önemli bir duruma gelmektedirler. Bu durumun ilk adımı ise merdivenin bir merdiven sofası içinde çözülmesiyle atılmışıı. Daha çok iç sofalı plan 
tipine sahip konutlarda merdiven için ayrı bir bölüm olduğu (Görsel 17) ve 19. yüzyıl sonlarına gelindiğinde merdiven sofasının daha fazla önem kazandığı görülmektedir (Eldem, 1954, s. 21).
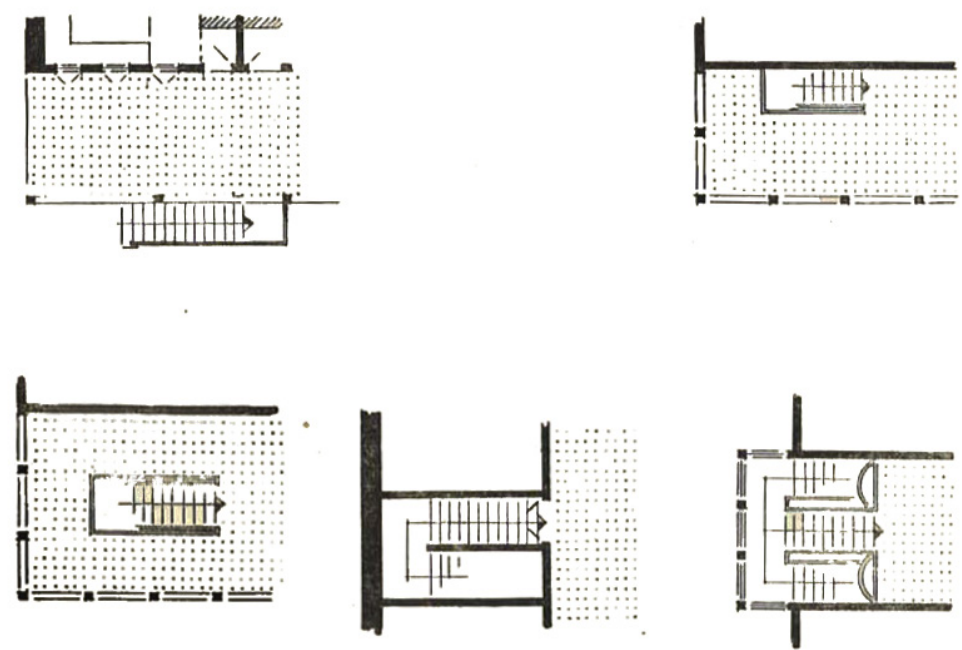

Görsel 17. Geleneksel Türk evinde merdivenin plandaki konumları (Eldem, 1954, s. 21)

\section{Geleneksel Türk Evlerinin Plan Özellikleri}

Geleneksel Türk evi plan şemaları; sofasız, dış sofalı, iç sofalı ve orta sofalı plan şemaları olarak sıralanabilir (Görsel 18) (Eldem, 1954, s. 22). Plan şemalarının özgün niteliklerinin başında, odaların sofanın uzantısı olarak ayrı mekanlara dönüşmesi ve yine sofada birbirleriyle bağlantı kurması gelmektedir.

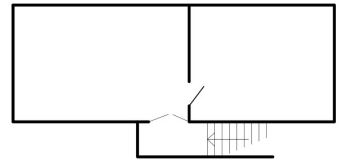

(a)

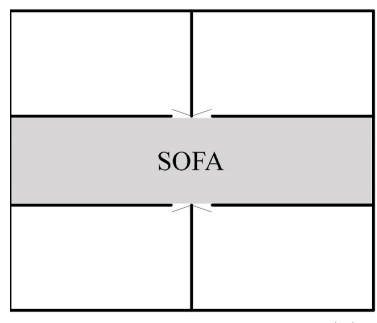

(c)

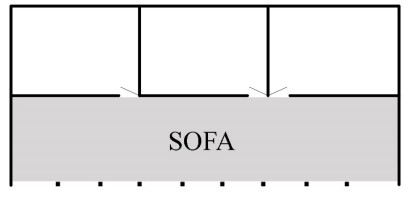

(b)

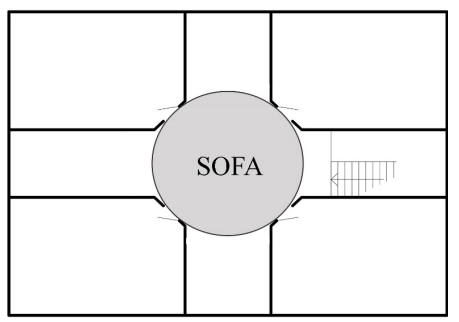

(d)

Görsel 18. Geleneksel Türk evlerinin plan şemalarının gösterimi a) sofasız b) dış sofalı c) iç sofalı d) orta sofalı 
Sofasız plan tipinde, plan şemasını oluşturan odalar yan yana dizili haldedir (Görsel 19). Odalar arasında geçiş; kaldıım, tretuvar veya bir avluyla sağlanmıştır (Eldem, 1984, s. 18). Sofanın veya hayatın yerini bu plan tipinde taşlık veya bahçe almışır (Görsel 20). İki katlı örneklerinde ise üst katta odaların bir balkonla (gezemek) bağlandığı görülmektedir (Bekłaş, 1996, s. 99). Bu durum daha çok sıcak iklime sahip olan güney yerleşimlerinde görülür. Soğuk iklimin hâkim olduğu yörelerde ise bu geçişin üzeri kapatımış ve bu plan şeması çok fazla tercih edilmemiştir. Bu plan şemasının en basit şekli avluya açılan tek odalı ev tipidir. Oda sayısı arttıkça odalar yan yana dizilir ve genellikle kapı ve pencereleri aynı cepheye bakar. Odaların arasında bir eyvan bulunabilir. Oda sayısının çok fazla olduğu durumlarda oda sırasının bir ya da iki ucunda kollar devam edebilmektedir (Görsel 21 ) (Eldem, 1984, s. 18).
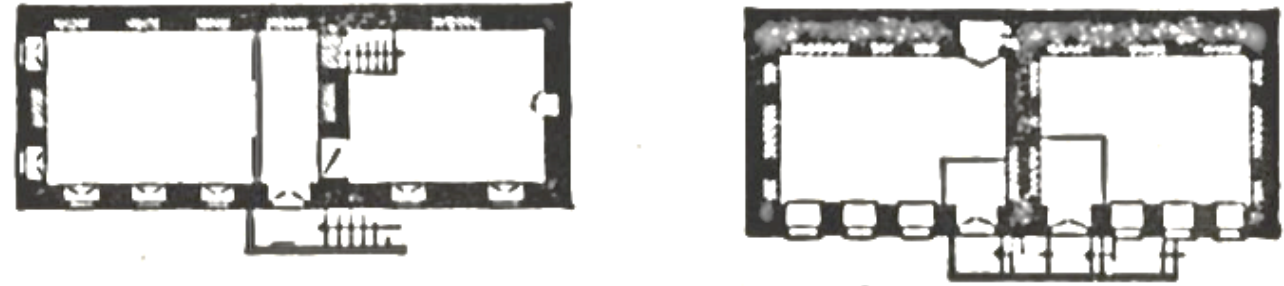

Görsel 19. Müfit Arif Efendi Evi (Gaziantep), Şehireküstü Mahallesinde bulunan bir ev (Gaziantep) (Eldem, 1954, s. 27)

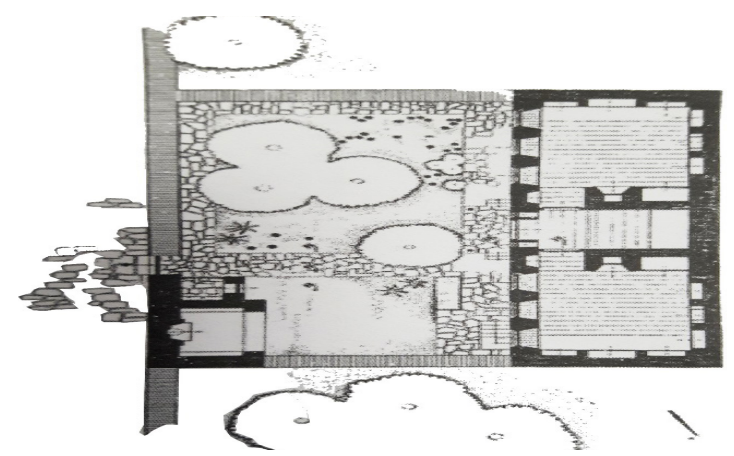

Görsel 20. Hacı Kadirlerin Evi, Konya (Berk, 1951, s. 61)

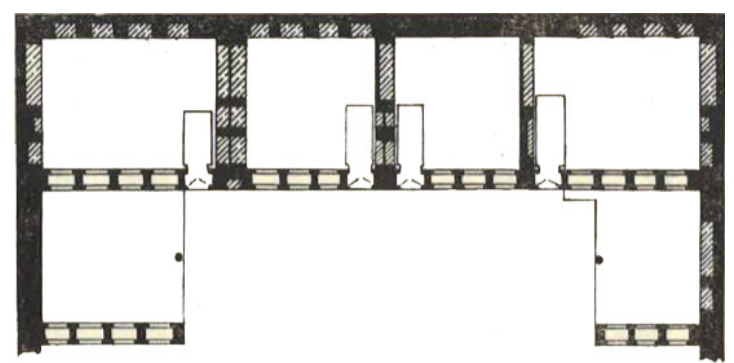

Görsel 21. Ahmet Kavukçu Evi, Antalya (Eldem, 1984, s. 32) 
Dış sofalı plan tipinde, odalar yan yana sıralanır ve bir sofa ile birbirine bağlanır. Sofa, kapalı alanın dışında yer alır. En ilkel örneklerinde sofa, üzeri damlı, açık bir direklikten oluşur. İklimin uygun olduğu bölgelerde bu tip kullanılmaya devam edilmiştir. Zamanla, yaşam düzeyi yükseldikçe sofa kapatımaya başlanmıştır. Sofanın yanındaki pencereli duvarlar bu dönüşümün ilk adımıdır. Sonrasında sofa tamamen kapatımıştır. Önceleri camekanla kapatılan sofa daha sonra büyük pencerelerle yapılmıştır. Oldukça sade olan bu plan tipine zenginlik katan elemanlar eyvan ve köşklerdir. Sedad Hakkı Eldem, dış sofalı plan tipini kendi içinde şu şekilde sınıflandırmaktadır:

Dış sofalı, tek odalı plan tipi

Dış sofalı, iki odalı plan tipi

Dışs sofalı, eyvanlı plan tipi

Dış sofalı, iki odalı ve köşklü plan tipi

Dış sofalı, köşklü ve eyvanlı plan tipi

Dış sofalı, bir ucu odalı plan tipi

Dış ve köşe sofalı plan tipi

Bir veya iki kollu oda sırasıyla çevrilmiş dış sofalı plan tipi (Eldem, 1984, s. 18).

Dış sofalı plan tipi, odaların dizilimi ve sofanın konumuna göre de farklılık göstermektedir. Odaların; sofanın bir yanına dizildiği, sofanın birbirine bitişik iki yanına dizildiği (Görsel 22) ve sofanın üç kenarında da var olduğu (Görsel 23) durumlar vardır (Bektaş, 1996, s. 99-101).
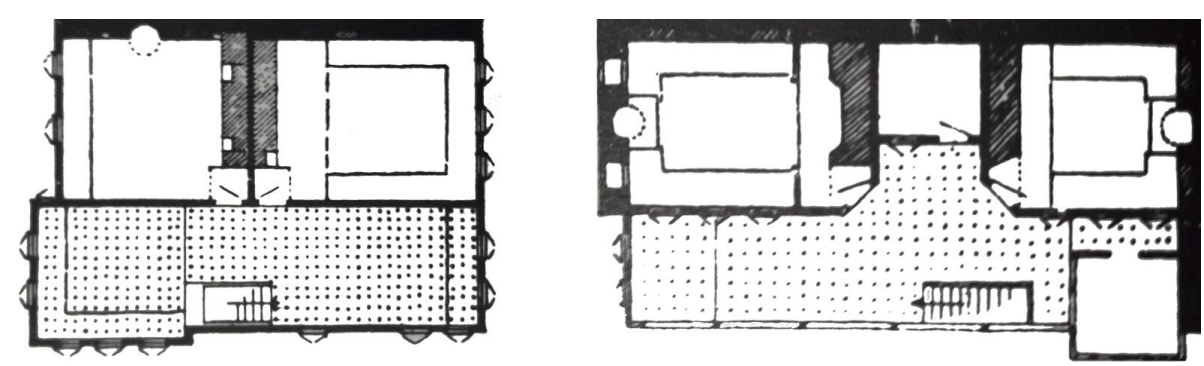

Görsel 22. Emin Bekim Oğlu Hüsnü Evi (Gebze), Hacı Rıza Evi (Bergama) (Eldem, 1984, s. 32) 

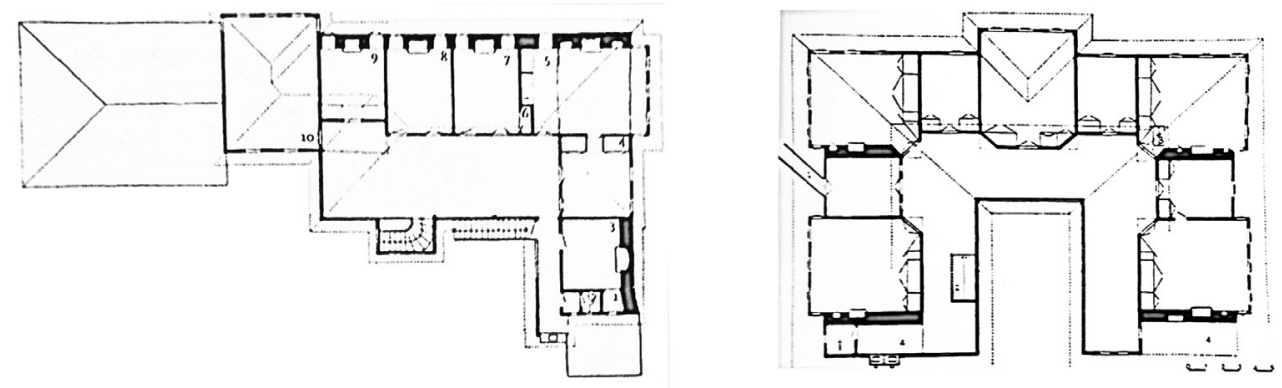

Görsel 23. Hasan Bey Evi (Antalya), Hacı Ömer Ağa Evi (Antalya) (Bektaş, 1996, s. 101)

İç sofalı planlarda, sofanın her iki yanında odalar yer alır (Görsel 24). Bu plan tipi "karnıyarık" olarak da adlandırımaktadır. İç sofalı plan şemasına sahip evlerde genellikle sofanın iki yüzünün de açık tercih edildiği görülür. Sofanın bir yüzünün sağır bırakıldığı evlerde bunun nedeni genellikle kullanım ya da topografik sebeplerden Ötürüdür. Sofanın iki yanı da çıkma olarak devam edebilir. Sedad Hakkı Eldem, iç sofalı plan tipini kendi içinde şöyle sınıflandırmaktadır:

İki yüzlü, iç sofall, iki odalı plan tipi

iki yüzlü, ikiden fazla odalı, iç sofalı plan tipi

Bir yüzlü, iç sofalı plan tipi

Eyvanlı ve yan sofalı plan tipi (Eldem, 1984, s. 18).
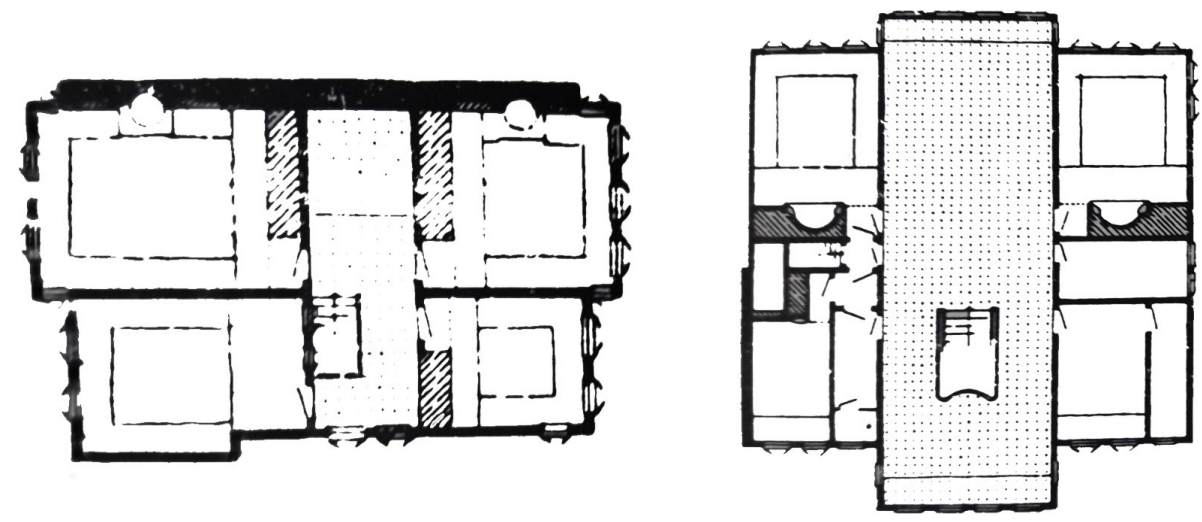

Görsel 24. Bir yüzlü iç sofalı plan tipi örneği Nalbant Kadri Usta evi (Gebze), iki yüzlü iç sofalı plan tipi örneği İntizam Ağası Hüseyin Bey evi (istanbul) (Eldem, 1984, s. 34, 35)

İç sofalı plan tipinin tercih edilme sebebi ekonomik ve kullanışlı olmasıdır. Odaların sofanın iki yüzüne sıralanmasıyla dış duvarlardan tasarruf sağlanır. Odalar arasındaki geçiş açısından kolaylık sağlar. Öte yandan sofanın bahçe ile bağlantısı zayıflamıştır. Bu nedenle daha çok şehir yerleşimlerine uygun bir karaktere sahiptir 
(Eldem, 1954, s. 25; Eldem, 1984, s. 18).

Orta sofalı plan tipinde, plan şemasının merkezinde sofa yer almaktadır. Sofanın dört tarafında odalar dizilidir. Sofanın ışık alabilmesi için odaların arasında eyvanlar yer alır. Eyvan sayısının birden dörde kadar çıktığı durumlar vardır. Bu örnekler iç sofalı plan tipinin en gelişmiş örnekleridir. Bu nedenle bu planların daha büyük programlı ve varlıklı olarak nitelendirilebilecek hane halkına sahip konutlarda uygulandığı söylenebilir. Sedad Hakkı Eldem, orta sofalı plan tipini şöyle sınıflandırmaktadır:

Dört köşeli, orta sofalı plan tipi

Pahlı köşeli, orta sofalı plan tipi

Yuvarlak veya beyzi, orta sofalı plan tipi
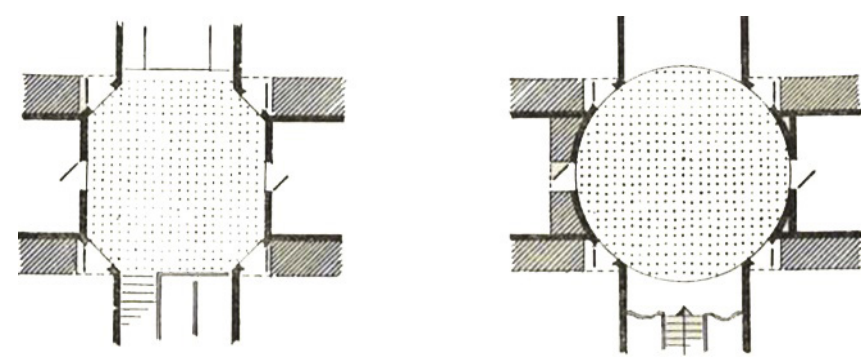

Görsel 25. Pahlı ve yuvarlak sofaların plan şemasındaki karakteristik durumu (Eldem, 1954, s.
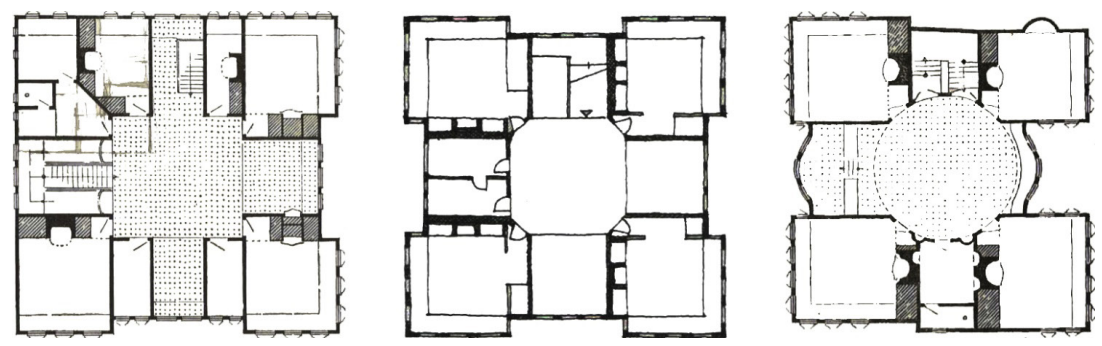

Görsel 26. 1. Dört köşeli orta sofalı plan tipi örneği (Vasıf Bey Konağı, Bolu) (Eldem, 1954, s. 133); 2. Pahlı orta sofalı plan tipi örneği (Gökçüoğlu Evi, Safranbolu) (Sözen, 200 I, s.92); 3. Yuvarlak orta sofalı plan tipi örneği (Abacı Yorgi Evi, Filibe) (Eldem, 1954, s. 142)

Orta sofalı plan tipinde sofaya farklı biçimler uygulanmıştır. En çok tercih edileni sofanın köşelerinin pahlanmasıdır. Bu şemada sofa düzgün olmayan bir sekizgen formundadır. Zamanla sofa oval forma dönüşmüştür (Görsel 25, Görsel 26). 


\section{$\operatorname{arts}=$}

\section{Geleneksel Türk Evlerinin Cephe Özellikleri}

Cephe; kentsel dokunun oluşumunun bir parçası ve yapının dışarıdan algılandığı dış yüzüdür. Geleneksel Türk evlerinin cepheleri, farklıyörelerin tarihsel süreç içerisinde elde ettiği kendine özgü kültür birikiminin önemli transfer araçlarındandır. Bölgenin kültürü ve tarihi ile birlikte sosyal ve ekonomik özelliklerinden, yapının inşa edildiği zamanın yapım yöntemlerinden ve malzeme kullanımlarından kent kullanıcılarına yansımalar sağlar. Dönemin bir yansıması olmakla birlikte, günümüz mimarisine de ışık tutarak örnek teşkil etmesi yönüyle de büyük öneme sahiptir.

Geleneksel Türk evlerinin özellikle Anadolu'da, bir ya da iki katlı örneklerine daha sık rastlanmaktadır. Bu durumu Sedad Hakkı Eldem, "Türk Evi umumiyetle bir katıdır. Ancak, zaman ile kat adedi fazlalaşmıştır. Öyle olmakla beraber, daima esas kat tektir. Bu esas kat ise birkaç katı evlerde mutlaka en yukarıdadır. En basit ve alçak ev tiplerinde yalnız bir kat mevcuttur." şeklinde açıklamaktadır. (Eldem, 1954, s. 12; Ak, 2016). Iki ya da daha fazla katı evlerde giriş katın servis mekanlarını barındırması, bu katın cepheye yansımasını da daha sade kılmıştır. Üst katta/katlarda yaşama mekanlarının yer alması ise bu katların cephelerinde hareketliliği artırmıştır (Görsel 27, Görsel 28, Görsel 29, Görsel 30).

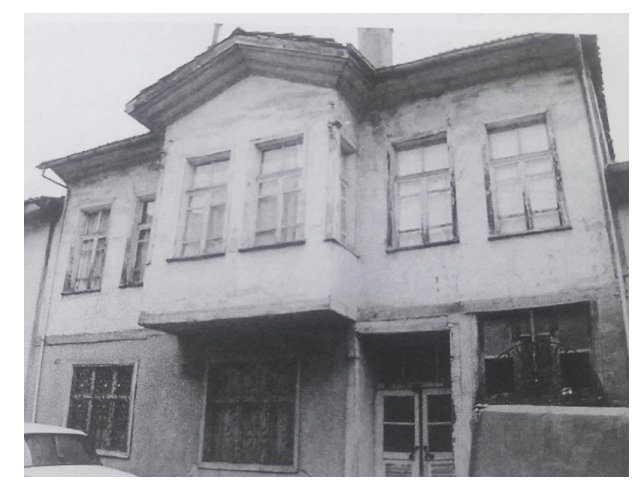

Görsel 27. Burdur Evi örneği (Urfalıoğlu, 2010, katalog no. 115)

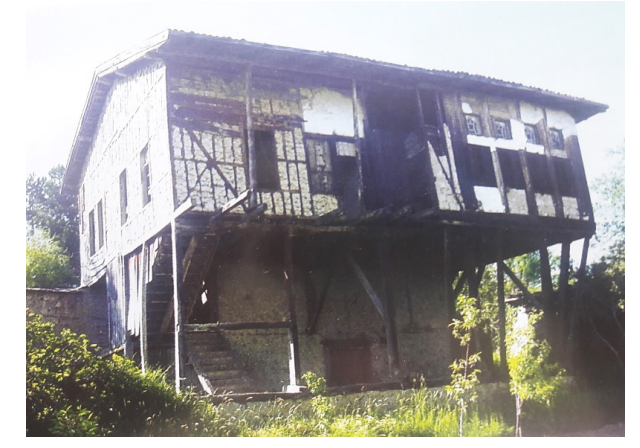

Görsel 28. Safranbolv Evi örneği (Küçükerman, 1985, s. 40) 


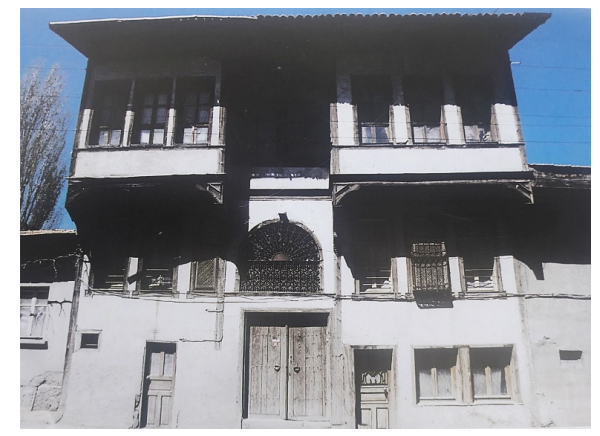

Görsel 29. Kütahya Evi örneği (Bektaş, 1996, s. 48)

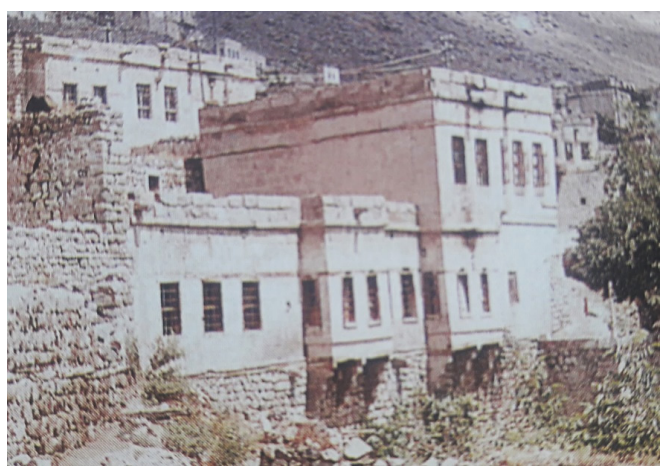

Görsel 30. Erkilet Evleri, Kayseri (Bektaş, 1996, s. 41)

Geleneksel Türk evinde cepheyi oluşturan önemli ögeler; çıkma, kapı, pencere, saçaklar ve cephede bulunan süslemelerdir. İç mekânda kullanımı kolaylaştırması, doğal ışıktan daha çok faydalanılabilmesi, konutun havalandırılması, evin sokakla ve sosyal hayatla ilişki kurabilmesi gibi gerekçelerle farklı tipte çıkmalar yapıldığı görülmektedir. Çıkmalacumbalar, sofanın plandaki uzantıları olan köşkler plan şemasının dışa yansımaları olarak cephede hareketlilik sağlayan ögelerdir (Görsel 31). Genellikle sokak cephesinde yer alan bu çıkmaların tipi ve boyutları da kendi içinde farklılıklara sahiptir. Örneğin Akdeniz Bölgesinde yer alan Antalya, ısparta ve Burdur evlerinde iç sofalı plan şeması, yapının cephesine tam ortada ve sıvasız ahşap çıkma şeklinde ya da sofanın üstünde üçgen/yuvarlak alınlıklı olarak yansır (Görsel 32) (Urfalıoğlu, 2010, s. 39). 


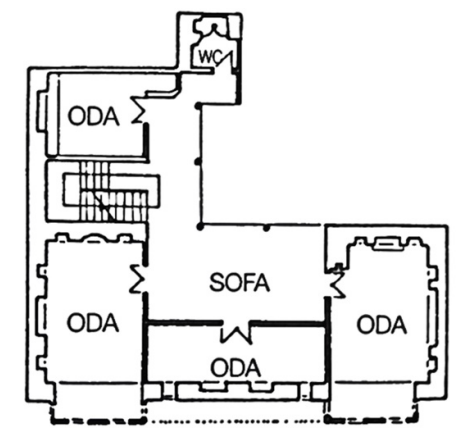

I. kat planı

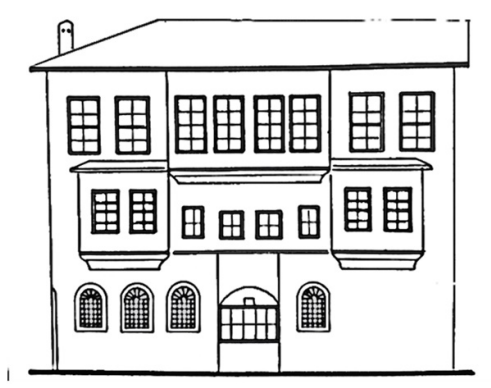

Görsel 31. Plan ve cephe üzerinde çıkmaların düzeni ve ilişkisi (Urfalıoğlu, 2010, katalog no.

8)

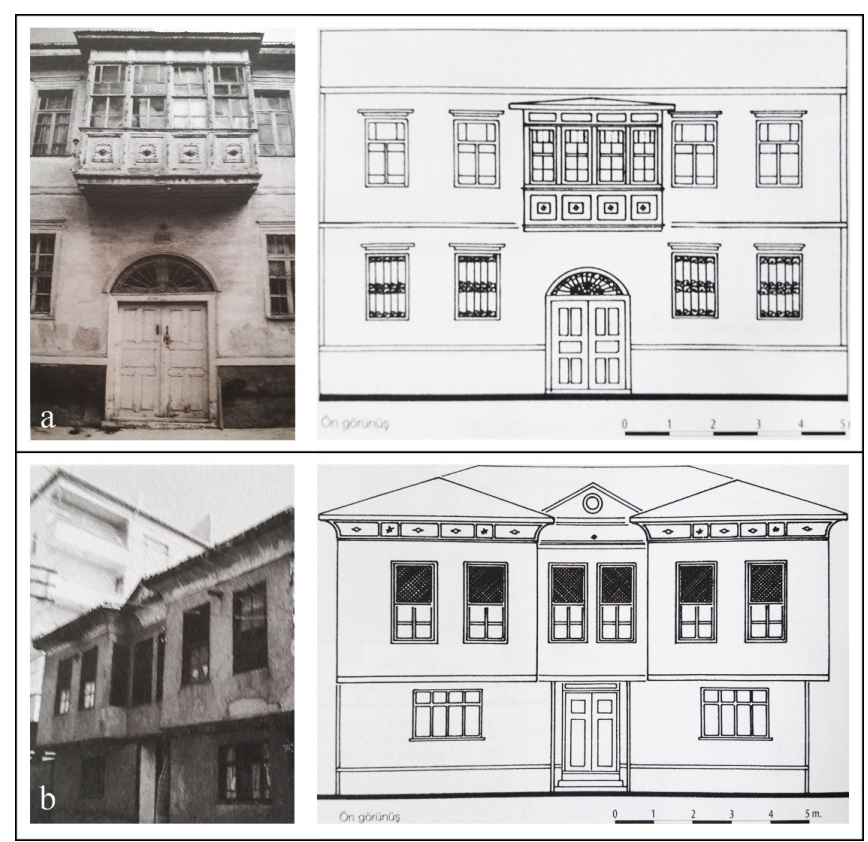

Görsel 32. a) Burç Mahallesi, Burdur b) Gazi Kemal Mahallesi, Isparta (Urfalıoğlu, 2010 katalog no. 119, 411)

Geleneksel Türk evinde kapı doğrudan sokağa veya bahçeye açılabilir. Bahçeden ulaşılan evlerde bahçe kapısı tarımla uğraşan ev halkı için daha kullanışlı olması, yaylı arabanın, yüklü atın kolaylıkla geçebilmesi gibi gerekçelerle genellikle çift kanatıdır. Genellikle kapının önünde gölgelik oluşturmak veya yağmurdan korunmak için bir saçak bulunur (Görsel 33). Evin giriş kapısı da genellikle çift kanatlı olmakla birlikte üzerinde dökme demir parmaklıkı bir pencere yer alır. Bu pencere sofayı aydınlatmak ve havalandırmak içindir. Bazı evlerde de giriş kapısının yanında dışarıya bakmak için bir selamlık penceresi bulunur. Kapıların tokmağı veya halkaları vardır (Görsel 34). Bunlar demiri tunç veya farklı metal alaşımlardan yapılmış olup evde yaşayan aile ile ilgili çeşitli semboller taşırdı. Evin zenginlik durumuna ve mimari özelliklerine göre kapının da görünümü değişirdi (Görsel 35) (Eldem, 1987, s. 80). 

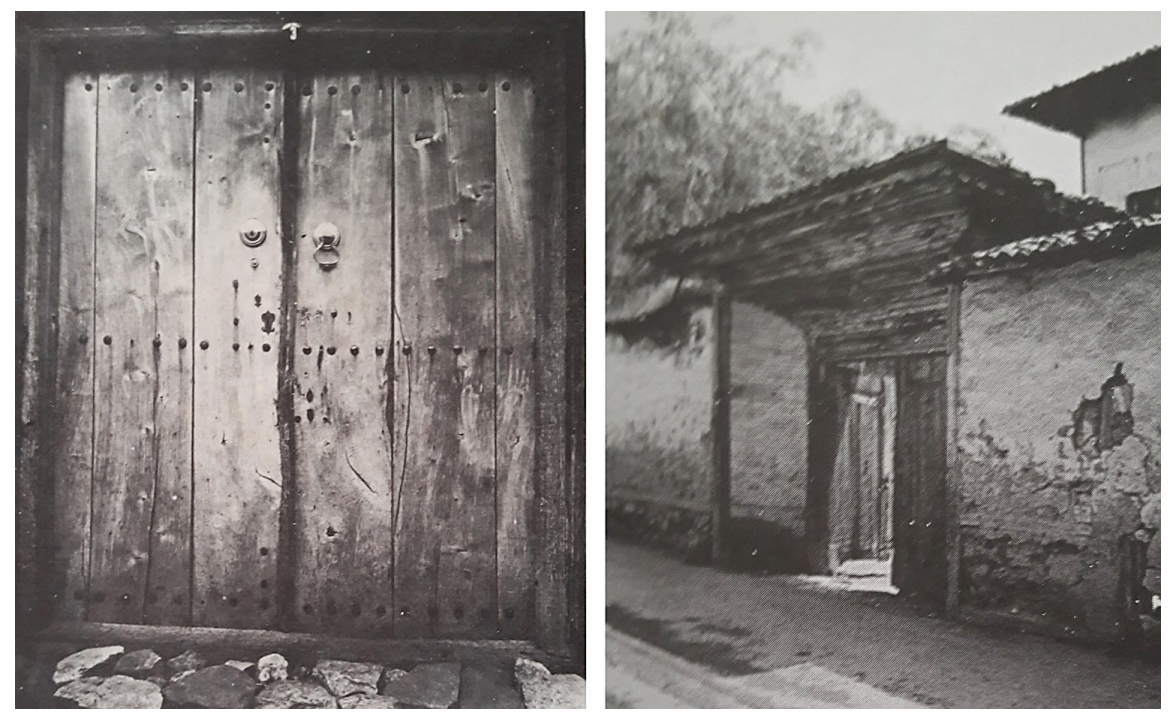

Görsel 33. Geleneksel Türk evinde bahçe kapısı örnekleri: 1. Bursa 2. Tokat (Bektaş, 1996, s. 78)
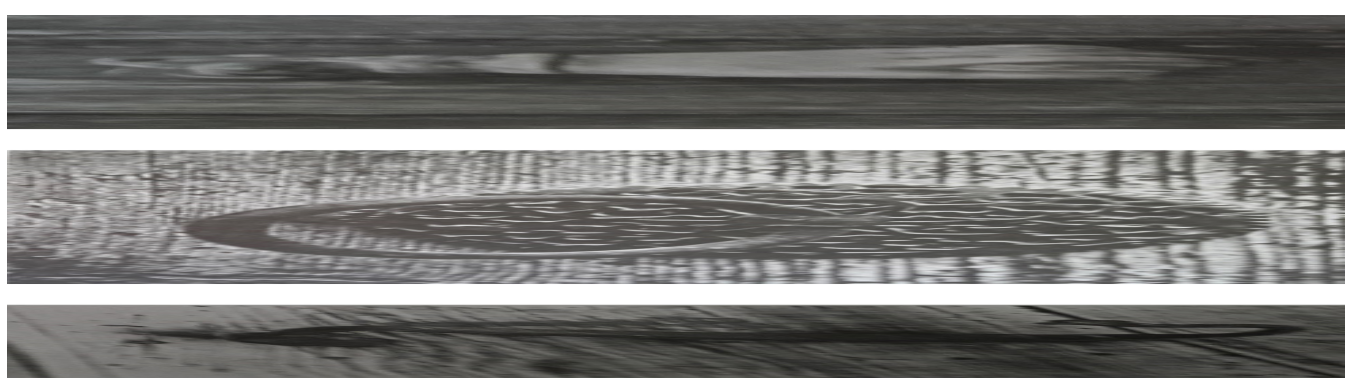

Görsel 34. Geleneksel Türk evinde kapı tokmağı ve halkası örnekleri (Bektaş, 1996, s. 80, 78, 81)
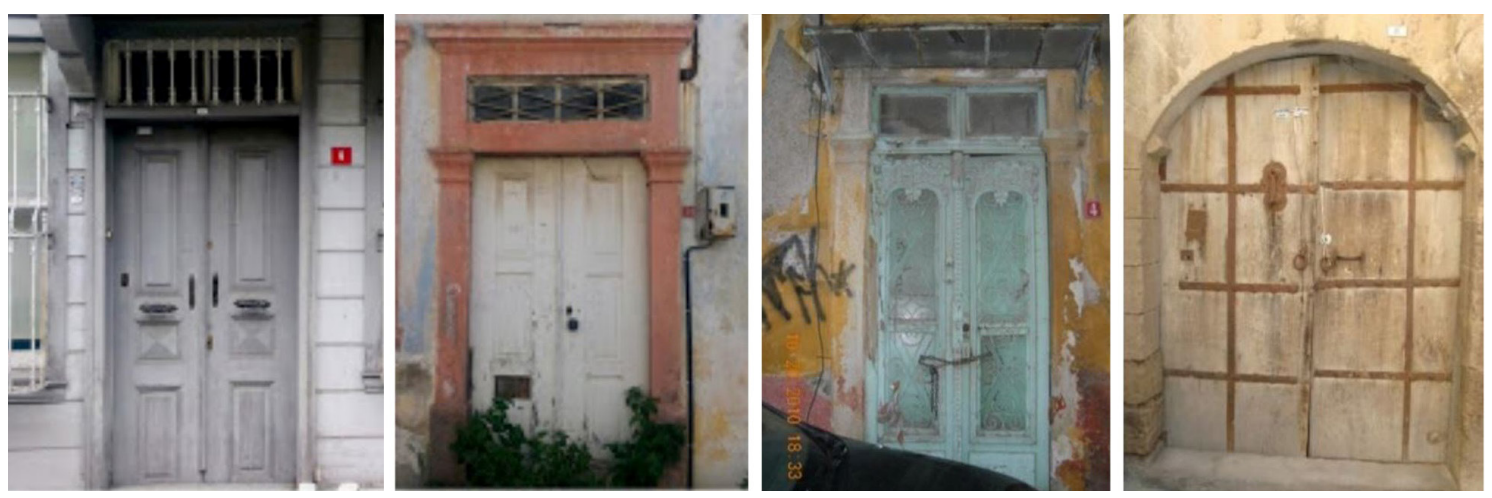

Görsel 35. Geleneksel Türk evi giriş kapısı örnekleri: 1. Kuzguncuk, İstanbul (Yılmaz, 2016); 2. Cunda, Balıkesir (Yılmaz, 2016); 3. Güzelyalı, İzmir (Çetiner, 2014, s. 38); 4. Mardin (Kılıç, 2010, s. 89) 


\section{$\operatorname{arts}=$}

Giriş kat ve üst katlardaki pencere düzenlerinin de birbirinden ayrıldığı görülmektedir. Genellikle servis mekanlarının bulunduğu giriş katında, kullanım amacı ve Anadolu kültüründen süregelen mahremiyetle de bağlantılı olarak pencere boyutları daha küçüktür. Aynı zamanda da bu kattaki pencereler göz seviyesinin yukarısında olacak şekilde düzenlenmiştir. Üsłat pencereleri ise yol kotuyla göz seviyesinde olmamaları ve aynı zamanda yaşama mekanlarına açılmaları nedeniyle daha büyük boyutlara sahiptir. Sıcaklık değişimleri nedeniyle bu durumun yaşama katında da farklııklar gösterdiği görülür. Kışlık ve yazlık oda düzenlemeleri cepheye de farklı düzenler getirir. Konutun yönü ve odanın konut içindeki konumu dikkate alınarak düzenlenmiş yazlık odadaki pencerelerin boyutları daha büyüktür. Daha korunaklı olması istenen kışlık odaların ise pencere boyutları daha küçüktür. Pencerelerde genellikle ölçü olarak 1/2 oranı vardır (Görsel 36, Görsel 37) (Kuban, 1995, s. 122-124; Küçükerman, 1985, s. 38-41; Perker, 2012, s. 6) Öte yandan tepe pencereleri, pencere kapakları ve kafesleri de geleneksel Türk evinin cephe dilinin oluşumunda diğer önemli ögelerdir (Görsel 38).
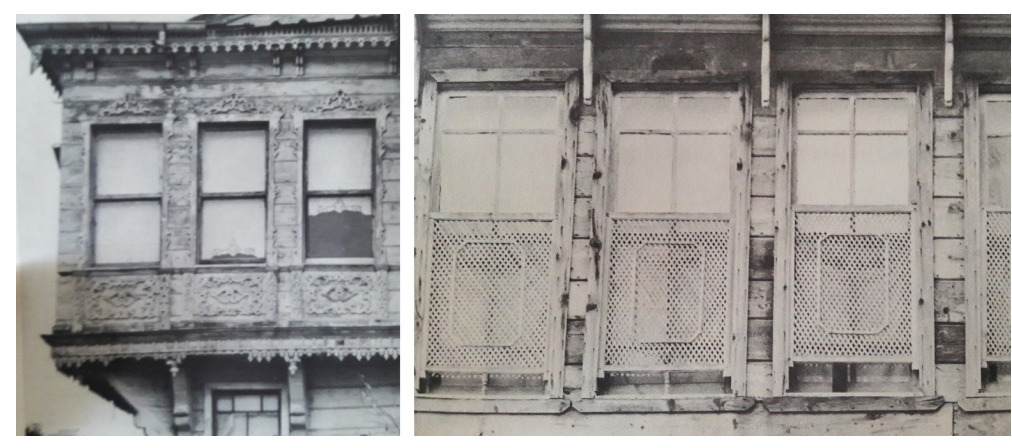

Görsel 36. Geleneksel Türk evi pencere örnekleri (Eldem, 1987, s. 102, 103)

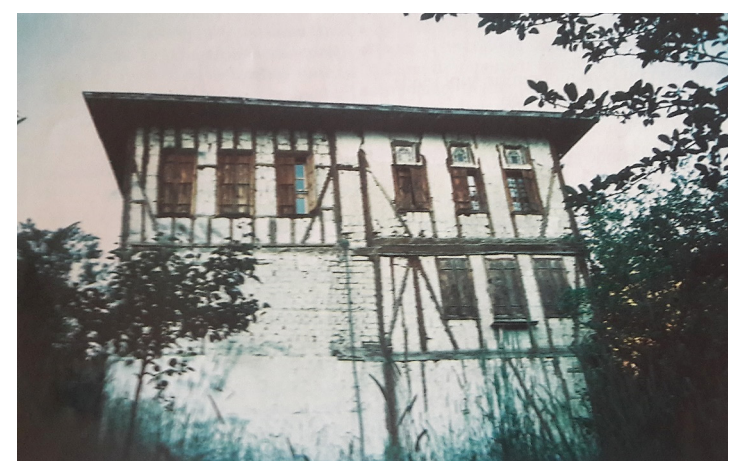

Görsel 37. Pencere düzeninin giriş kat-üst kat ve kışık-yazlık oda değişkenlerine bağlı olarak değişimi, Safranbolu örneği (Küçükerman, 1985, s. 41) 

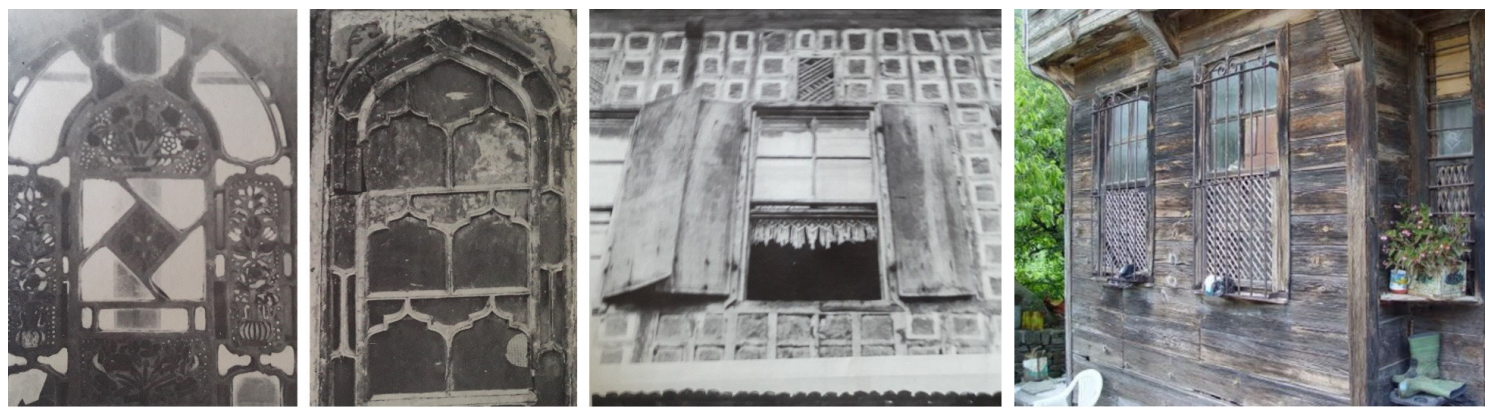

Görsel 38. Geleneksel Türk evinde tepe penceresi örnekleri (Eldem, 1987, s. 105),

Trabzon'da pencere kapağı örneği (Küçükerman, 1985, s. 127), İstanbul'da pencere önünde kafes örneği (Kara,

Geleneksel Türk evlerinin bir diğer özgün ögesi de saçaklardır. Saçaklar bazı konutlarda çıkmaları takip ederken, bazı konutlarda ise düz ve bütüncül bir şekilde devam eder. Süslü kenarlıklı saçaklar cephe hareketliliğine katlı sağlayan ögelerdir. Çıkma, saçak ve cephede süsleme kullanımının en yaygın olarak karşılaşıldığı dönemler özellikle 18. yüzyılın son dönemleri ile 19. yüzyıldır (Kuban, 1995, s. 37-39; Sezgin, 2006, s. 6).

Konutun inşa sürecinde kullanılan yapım yöntemi ve malzeme seçimi de cephe kimliğinin ortaya çıkmasındaki bir diğer etkendir. Anadolu'nun farklı yörelerinde, bölgenin jeolojik yapısına ve iklimine bağlı olarak farklı malzeme kullanımlarının olduğu görülmektedir. Bazı durumlarda giriş katı tamamen taş ile yükseltilerek, ikinci kat ahşap veya ahşap çatkı arası tuğla ya da kerpiç devam ederken; taş temel üzerine kerpiç duvarların inşa edildiği örnekler de mevcuttur. Yöreden yöreye değişim gösteren bu oluşumlar, farklı yerleşim bölgelerinde cephe dilinde farklılıkların ortaya çıkması sonucunu doğurmuştur.

\section{Geleneksel Türk Evlerinin Süsleme Özellikleri}

Süslemenin tanımlamalarına bakıldığında Uğur Tanyeli ve Metin Sözen, "Bir yüzeyi estetik açıdan daha etkileyici kılmak amacıyla üzerinde yapılan her türlü çalışma" olarak tanımlarken (Sözen ve Tanyeli, 1992, s. 223), Nejat İşcan, "Bir binayı eşyayı kullanış amacına göre hoş görünüm sağlamak için yapılan estetik çalışma" olarak tanımlamaktadır (İşcan, 1979, s. 3). Geleneksel Türk evinin oluşumunda planın etkisi kadar cephenin de önemli bir etkisi vardır. Cephedeki kapı, pencere ve çıkma gibi mimari elemanların yanı sıra cephede uygulanan süslemelerin de cephe dilinin oluşumunda önemi büyüktür. Sıvanın üzerine yapılmış kalemişi süslemeler, 


\section{arts}

köşe dikmeleri, alçı ve diğer süslemeler cephenin karakterini etkileyen faktörlerdir (Urfalıoğlu, 2010, s. 57; Demirbağ ve Urfalıoğlu, 2021, s. 267-268). Geleneksel Türk evinin içinde ise diğer mekanlara göre odalarda daha çok süsleme olduğu görülür (Kahraman, 1997, s. 68).

Süslemeler değerlendirildiğinde; süslemelerin uygulanma miktarlarının, kullanılan tekniklerin ve malzeme kullanımlarının, ev sahibi ailenin mali durumu ve sosyal statüsü dikkate alınarak belirlenen ve ayrıca ustanın kabiliyetine bağlı faktörler olduğu sonucuna varılmaktadır (Diler ve Erbil, 2017, s. 803). Öte yandan evlerin sahip olduğu süslemeler, yapıldığı dönemde hâkim olan mimari üsluptan, toplumun sosyal yaşantısından ve geleneklerinden izler taşır.

Geleneksel Türk evinin geçmişine bakıldığında 16. yüzyıl ve öncesindeki mimari özelliklerden bahsetmek oldukça güçtür. Bu dönemlerde tercih edilen malzeme, yapım teknikleri ve diğer etmenlerle birlikte mahallelerde sık sık çıkan yangınlar da evlerin sürekli yenilenmesine neden oluştur. Bu nedenle Anadolu'da 16. ve 17. yüzyıla kadar, tarihlenebilecek evlerin sayısı çok azdır (Eldem, 1984, s. 7-9). Var olan kısıtlı bilgiler ışığında süslemelerin renkli "malakari" ve kalemişi tekniğinde olduğu, ocak davlumbazı ve hücrelerin alçıdan süslere sahip olduğu söylenebilmektedir (Eldem, 1984, s. 40-41; Günay, 1999, s. 42).

17. yüzyılın ortalarından itibaren odalar sokağa çıkma yapmaya ve pencerelerle sokağa açılmaya başlamıştır. Tepe pencereleri küçük ve geometrik ya da cami, mihrap, minber, köşk ve selvi desenlidir (Görsel 39) Pencere kapakları dışa açılmaktadır (Görsel 40). 18. yüzyılda kapatılmaya başlanan sofanın direkleri kemerli, bağdadi sıvalı ve nakışlıdır (Görsel 41). Çıkmalar uzun, eğri desteklerle taşınmaktadır. Bu destekler üzerine de çeşitli süslemeler yapılmışıır. Tepe pencereleri daha yüksek yapılmıştır. Dış cephelerde boyanın kesme taş ve tuğla almaşık desenli olarak çizilmesi zamanla şematik bir süslemeye dönüşmüştür (Görsel 42).
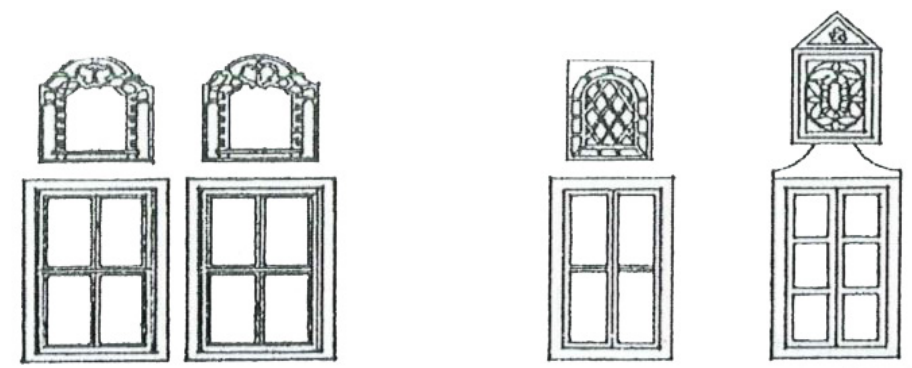

Görsel 39. Geleneksel Türk evinde kullanılan tepe penceresi örnekleri (Işık ve Yıldııım, 2002, s. 33) 

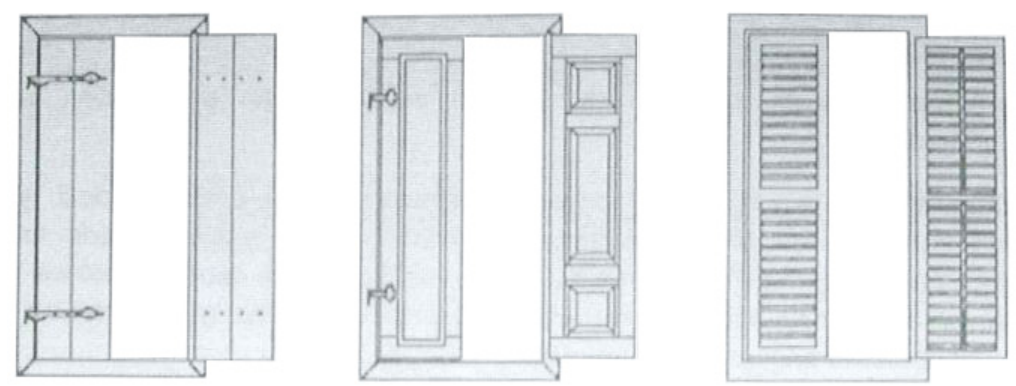

Görsel 40. Geleneksel Türk evinde kullanılan pencere kapak örnekleri (Işık ve Yıldııım, 2002, s. 32)
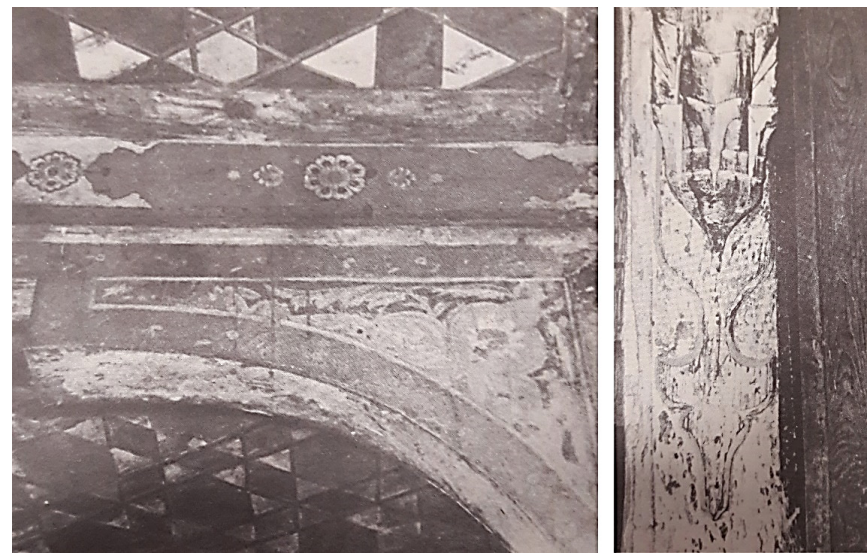

Görsel 41. Üzerinde hala bir kısım nakışları görülebilen Bursa kemeri - Halil Ağa Evi, Mudanya (Eldem, 1984, s. 99)
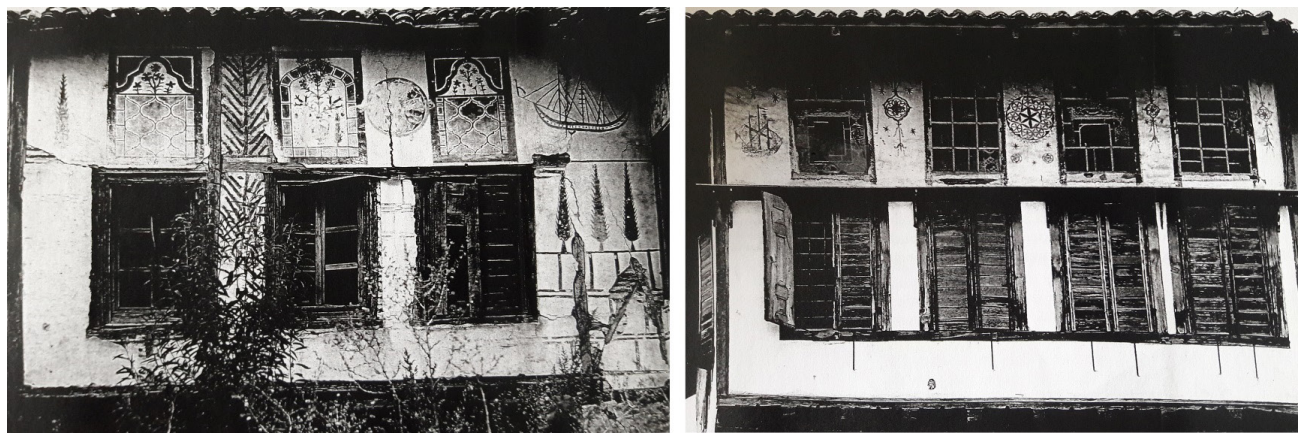

Görsel 42. Geleneksel Türk evinde kullanılan tepe pencereleri, yalancı tepe penceresi, pencere kapakları, geometrik süslemeler, dönemin sıklikla kullanılan gemi ve selvi resimleri, taş-tuğla almaşık desenli bezemelerin olduğu örnekler (Günay, 1999, s. 40)

18. yüzyılın ortalarına kadar evin asıl yapısında çok fazla değişiklik olmasa da yeni üsluplar dekorasyon ve süslemede kendini göstermiştir. 18. yüzyıla kadar evler daha derli topluyken Barok üslubunun geleneksel Türk evine nüfus etmesiyle bu durum değişmiş, cepheler hareketlenmiş, çıkma sayıları fazlalaşmış, çıkma altları 
ve saçaklar eğri yüzeyli, bağdadi sıvalı yapılmaya başlanmış ve çeşitli nakışlarla süslenmiştir. Süslemelerde kalem işleri duvarlarda, raf üstlerinde çerçeveli bölümlerde çiçek demetleri, çiçekli vazolar (Görsel 43), sepet veya kâse içinde meyveler, perde desenleri, ince yapraklı kıvrımlı dallar, sonra akantlar, girlandlar, volütler ve perspektif denemeleriyle görülmeye başlanır.
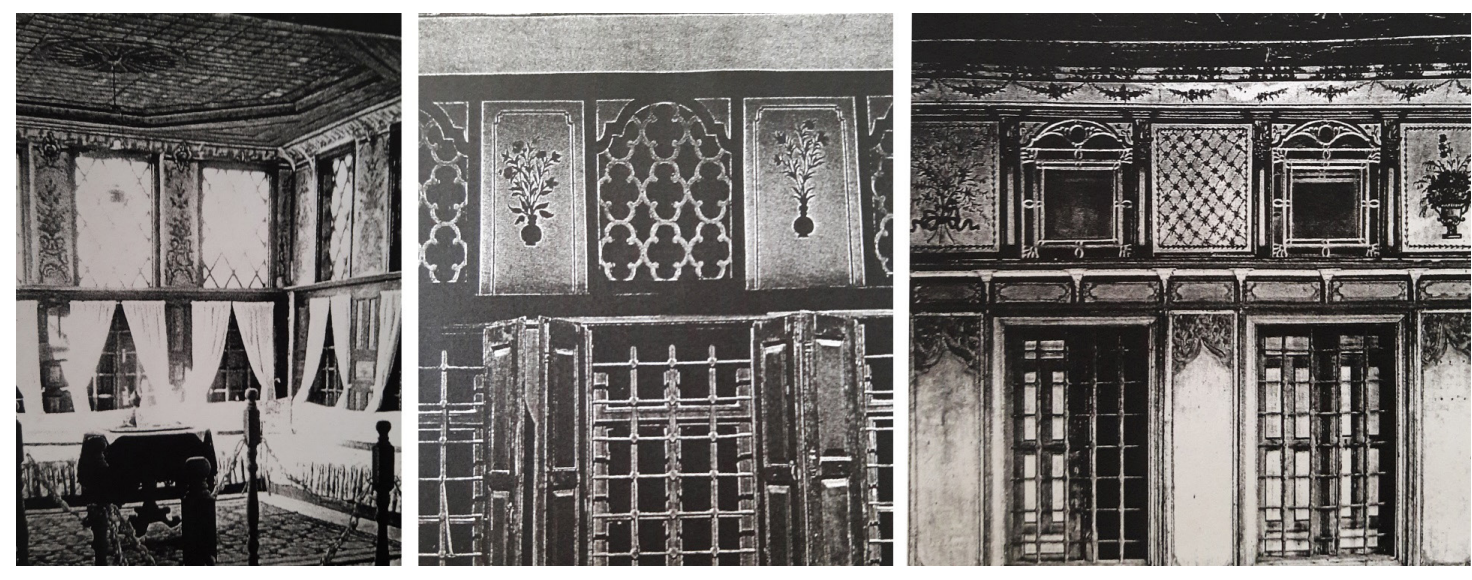

Görsel 43. Geleneksel Türk evinin duvarlarında yer alan bezemeler, dönemin modası olan vazoda çiçek resimleri (Günay, 1999, s. 50, 52)

Dış cephede içe göre bu uygulamaların daha az olduğu görülür. Yüklüğün üzerine denk gelen duvar bölümlerinde ise şehirden manzaralar yer almaya başlar (Görsel 44). Kırmızı, mavi ve altın yaldız en çok kullanılan renkler olmuştur. Ahşap yüzeylerde ise "Edirnekari" olarak adlandıılan yağı boya çiçek resimleri uygulanmış ve bu uygulamalar en çok dolap kapaklarında yapılmıştır (Görsel 45). Illk olarak Edirne'de ortaya çıkan teknik, daha sonra İstanbul, Bursa, Diyarbakır ve Erzurum başta olmak üzere Anadolu'nun birçok yerinde yaygın bir biçimde kullanılmıştır (Ünver, 1965, s. 16). Tavanlarda spiral göbekler yapılmıştır (Görsel 46). Çarkıfelek motifi tavanlarda sıklıkla kullanılmıştır. Ocak davlumbazları alçıdan ve bazen de mermerden Barok kıvrımlı olarak yapılmıştır (Görsel 47). Ahşap oymalar da Barok kıvrımlardan etkilenmiş̧ir. Köşe kapıların üzerinde yer alan pahlı bölümler kavislerle tavana birleştirilmiş̧ir (Günay, 1999, s. 198-202). 

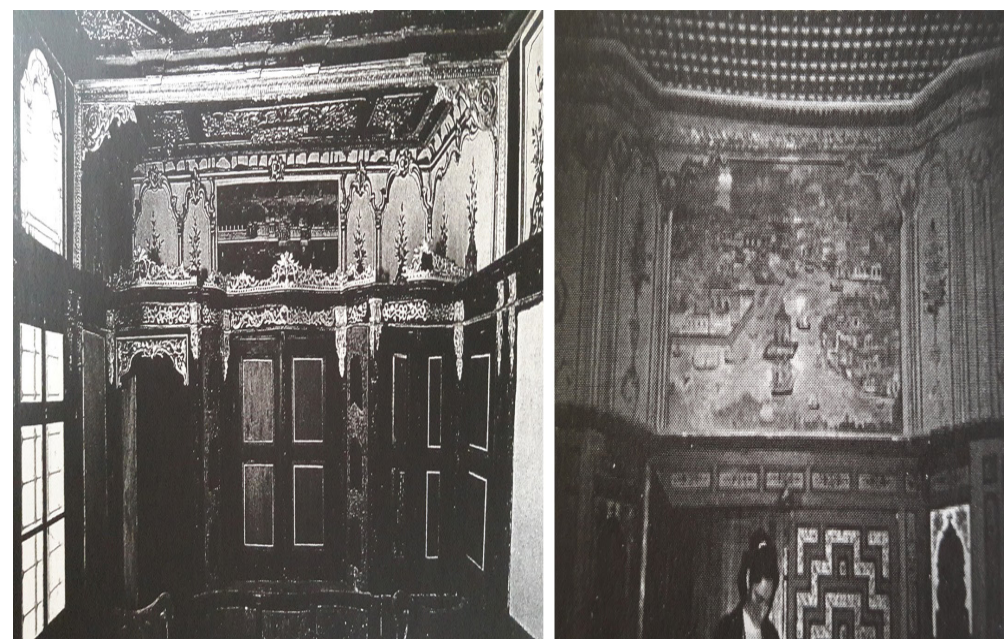

Görsel 44. Geleneksel Türk evinde manzaralı duvar resmi örneği: Yenişehir Şamaki Evi (Bektaş, 1996, s. 112)

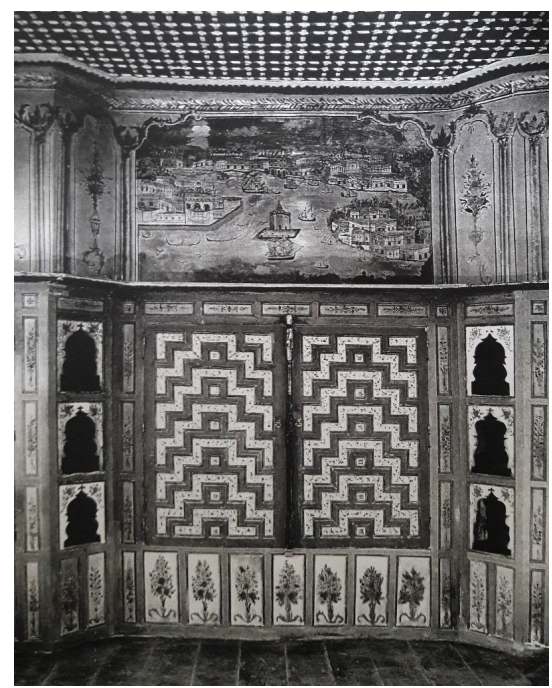

Görsel 45. Geleneksel Türk evinde Edirnekari dolap kapakları örneği ve dolap üzerine denk gelen duvar bölümünde manzara resimleri uygulaması, Şemaki Evi, Yenişehir, Bursa (Günay, 1999, s. 57)

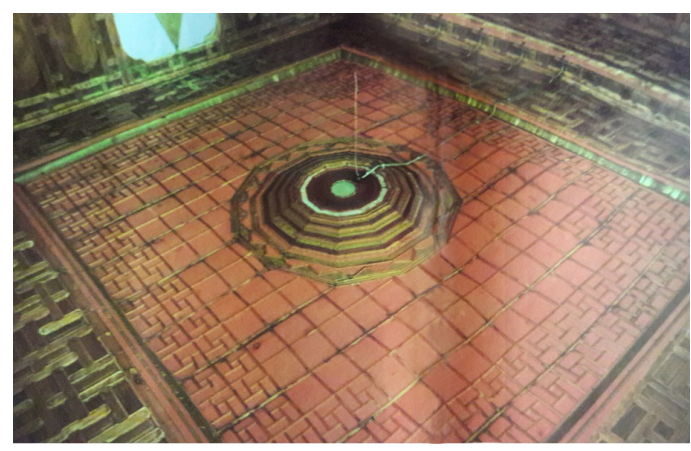

Görsel 46. Geleneksel Türk evinde aşağı sarkmış bir orta göbek örneği (Küçükerman, 1985, s. 162) 


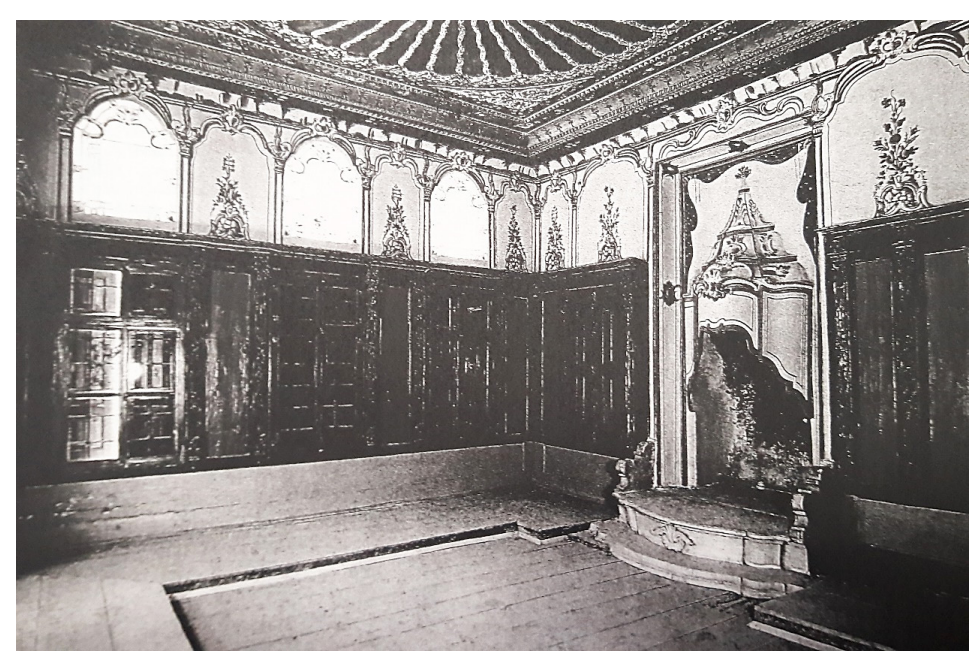

Görsel 47. Çarkıfelek motifli tavanı, tepe pencereleri ve Barok ocağıyla dönemin özelliklerini yansıtan bir oda örneği (Günay, 1999, s. 48)

19. yüzyılda plan, cephe ve süslemede Ampir üslubun etkileri görülmeye başlamıştır. Yalınlık ön planda olmuş, ince işlerin yoğunlukta olduğu evler daha sade ve aynı zamanda daha kaba bir görünüm almaya başlamıştır. Barok üslupta sık sık kullanılan eğrilikler azalmış yerini sade ve ciddi çizgilere bırakmıştır. Bu dönemde yaşanan bu değişikliklerin ekonomik nedenlerle bağlantısı da bulunur. Cephede yer verilen Toskana düzeninde yarım gömme sütunlar (pilaster), üçgen alınlıklar, kabartma kilit taşları, silmeler, şemseler, rozetler, çevresi ışınsal madalyonlar, tuğralar, girland motifleri, akant ve defne yaprakları, bayraklar, meşalelerle yapılan armalar, müzik aletleri, vazolar ve çiçekler Ampir üslubunda kullanılan öğeler olmuştur (Görsel 48) (Bozkurt, 2013, s. 44).
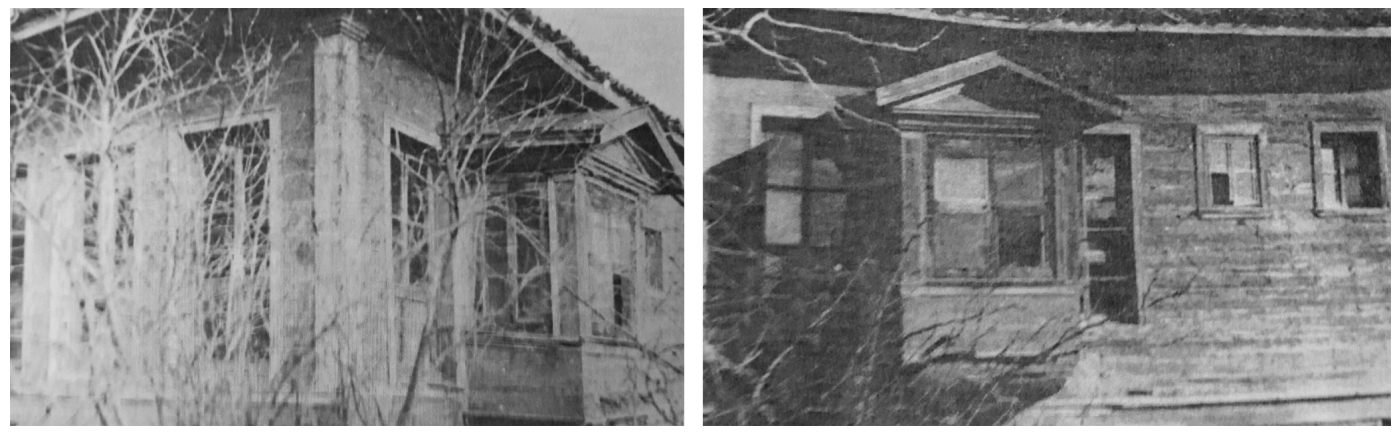

Görsel 48. Cephede Ampir üslupta üçgen alınlıklar, pilasterler ve silmelerin bulunduğu bir geleneksel Türk evi örneği (Eldem, 1984, s. 244) 
Pencere üstleri üçgen alınlıklı ya da yarım daire kemerli silmelerle bezelidir. İç duvarlarda alçıdan kabartma çıtalarla çerçeveler, bazen de içlerine kabartma çiçek demetleri yapılmıştır. Dolap cephelerinin daha yalın olduğu, ortasında yarım yuvarlak planlı bir "çiçeklik" nişi ve rafının yer aldığı görülür. Bunun iki tarafında yer alanlar ise "şerbetlik" olarak adlandırılır. Manzara resimleri ve teknolojinin getirdiği yeniliklerden olan tren, vapur gibi araçların resimleri nişlerin içine uygulanmıştır (Görsel 49). Abdülmecid döneminde Barok süslemeler Ampire katılırken, Abdülaziz döneminde süslemenin daha sade bir hal aldığı ve klasik Osmanlı üslubunun yeniden uygulandığı görülür. Duvarlarda dört bir yanda devam eden "sandalyalik" olarak adlandıılan silmeler yer alır. Tavanların sıvalı olduğu ve manzara resimleriyle süslendiği görülür. "Çiçeklik" ve "şerbetlik" daha az yapılır. Ocağın yerini ise çini soba almaya başlar (Günay, 1999, s. 43-44).

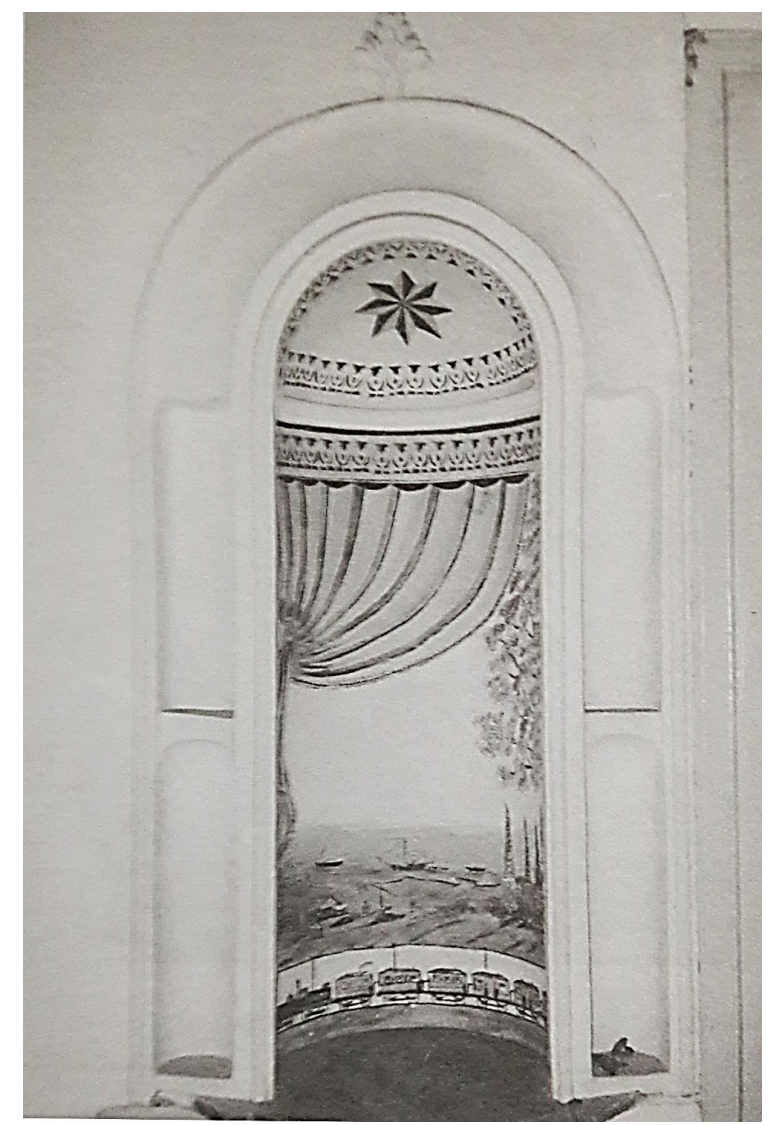

Görsel 49. Geleneksel Bir Türk Evinde oda nişinin içinde yer alan tren ve gemili resim, Isparta (Urfalıŏlu, 2010, katalog no: 61) 


\section{$\operatorname{arts}=$}

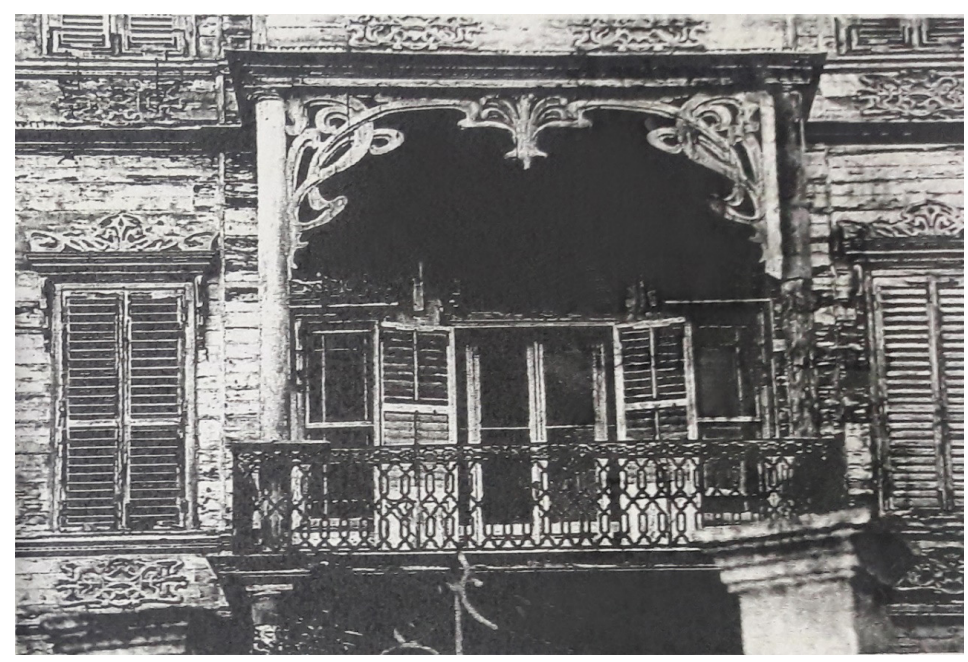

Görsel 50. Art-Nouveau üslupta balkon yaşmağı örneği, İstanbul (Günay, 1999, s. 42)

Art-Nouveau üslubu, Italyan mimar D'Aronco ile 1900'dètībaren İstanbul'da uygulanmaya başlamıştır. Yan yana sıralanarak genişletilmiş şekilde görünen standart pencerelerin üstleri küçük karelere bölünmüş ve renkli camlarla süslenmiştir. Art-Nouveau genellikle dönemin yaygın üslubu olan eklektik üslupla birlikte uygulanmıştır (Günay, 1999, s. 43-47). Çoğunlukla oyma ve aplike tekniğinde çiçek, dal, sarmaşık motifleriyle, birbirine paralel düz çizgiler, aynı ve değişik merkezli daireler bazen de elipsler görülmektedir (Görsel 50).

\section{SONUÇ}

Geleneksel Türk evlerinin mimari özellikleri, Anadolu'nun farklı bölgelerinde farklı özellikler göstermesiyle birlikle işleyiş ve kullanım açııından ortak özelliklere sahiptir. Geleneksel Türk evleri genellikle tek veya iki katı olarak inşa edilmişlerdir. En basit hali tek katı ve bir-iki odadan meydana gelen küçük programlı yapılar olmakla birlikte, bu evler genellikle kırsal kesimlerde yoğunlaşmışır. Şehirlerdekèvler ise genellikle iki katı yapılmıştır. Tek katlı olarak inşa edilen evlerin ise daha büyük ve çok odalı olduğu görülür. Oda, eyvan, avlu, hayat ve sofa gibi geleneksel Türk evine özgü elemanların, en basit plandan en gelişmiş olanına kadar, farklı düzenlemelere sahip olmakla birlikte genellikle aynı işlevi gösterecek şekilde organize edildiği görülmektedir.

Servis alanları, ambar, samanlık ve bazı örneklerde ahırın yer aldığı kat genellikle alt kattır. Yaşama mekanları ise genellikle üst katta bulunur. Anadolu 
evlerinin bazılarında zemin kat ve ana kat arasında bir kat daha bulunur. Özellikle dar parsel üzerinde inşa edilmiş, yoğun ve sık bir yerleşime sahip mahallelerde bulunan evlerde bu ara kata daha çok rastlanır. Ara kat, zemin katın tamamı üzerinde kurulan bir kat olmayıp, asma kat vazifesi görmektedir. Taşlık sofanın üzerini örtmemekte, sofanın kat yüksekliği bu durumda korunmuş olmaktadır. Özellikle 19. yüzyılda ara kat ve ana kat arasındaki farklar azalmıs; kat yükseklikleri de olmak üzere plan özellikleri ve kullanım amaçları bakımından da benzerlik göstermeye başlamışlardır. Böyle olmakla birlikte, üst kat ana(esas) kat olma özelliğini korumuştur.

Geleneksel Türk evi plan şemaları; sofasız, dış sofalı, iç sofalı ve orta sofalı plan şemaları olarak sıralanmaktadır. Kronolojik olarak bakıldığında en eski tiplerin dış sofalı çözümlere sahip olduğu, son örneklerin ise iç ve orta sofalı plan şemalarına sahip olduğu anlaşılmaktadır. Geleneksel Türk evinde cepheyi oluşturan önemli ögeler; çıkma, kapı, pencere, saçaklar ve cephede bulunan süslemelerdir. Çıkmalar, cumbalar ve sofanın plandaki uzantıları olan köşkler plan şemasının dışa yansımaları olarak cephede hareketlilik sağlayan ögelerdir. Cephedeki kapı, pencere ve çıkma gibi mimari elemanların yanı sıra cephede uygulanan süslemelerin de cephe dilinin oluşumunda önemi büyüktür. Katların kullanım şekillerine bağlı olarak, genellikle giriş katının daha sade, üst katlarda ise süslemelerin daha yoğun olduğu görülmektedir. İç mekânda ise, diğer mekanlara göre odalarda süslemenin daha yoğun olduğu anlaşılmaktadır.

GelenekselTürk evinin tasarım sürecininiçten dışa doğru olduğu görülmektedir. Modern mimarlık akımında yer aldığı haliyle, formun fonksiyonu takip etmesi olarak da ifade edilebilir. Bu durumun özellikle amaçlandığı söylenemez. Kendiliğinden gelişen bir süreç olduğunu ve formun/dışın önemsenmemesi gibi bir durumun da olmadığını söylemek mümkündür. Başka bir ifadeyle, geleneksel Türk evleri plan çözümleri kadar cephe ve süsleme özellikleri ile de özgün niteliklere sahiptir. Bu bağlamda, amacı Anadolu'daki geleneksel Türk evlerini; plan, cephe ve süsleme özellikleri çerçevesinde ele almak ve bütüncül bir bakış sağlamak olan çalışmanın, yerel mimari ve geleneksel konutlar üzerine yapılacak çalışmalara katkı sağlayacağı düşünülmektedir. 


\section{arts $=$}

\section{KAYNAKÇA}

Ak, H. (2016). Türk Evlerinin Tarihsel Süreci ve Plan Türleri. İç Mimarlık Dergisi. https://www.icmimarlikdergisi.com/2016/09/02/anadoluda-turk-evlerinin-tarihselsureci-plan-turleri/ Erişim Tarihi: 21 Şubat 2018

Ateş, M. (2008). Geleneksel Türk Konutlarının Plan Kurgusu ve Karakteristik Özelliklerinin Irdelenmesi, Restorasyon ile Birlikte Yeni Işlev Verilen İstanbul Konaklarının Incelenmesi. (Yayımlanmamış Yüksek Lisans Tezi). Haliç Üniversitesi Fen Bilimleri Enstitüsü, İstanbul.

Bektaş, C. (1996). Türk Evi (1. Baskı). İstanbul: Yapı Kredi.

Bektaş, C. (2005). Antalya Evleri: Anadolu Evleri Dizisi 2 (1. Baskı). İstanbul: Bileşim.

Berk, C. (1951). Konya Evleri (1. Baskı). İstanbul: itü Mimarlık Fakültesi.

Binay, İ. (2021). Geçmişten Günümüze Türk Mimarisinin Değişimi. Akademya Dergisi. https://akademyadergisi.com/gecmisten-gunumuze-turk-mimarisinindegisimi/ Erişim Tarihi: 07.07.2021.

Bozkurt, S. G. (2013). 19. Yüzyılda Osmanlı Konut Mimarisinde İç Mekân Kurgusunun Safranbolu Evleri Örneğinde Irdelenmesi. Journal of the Faculty of Forestry, 62(2), 37-70.

Cansever, T. (2002). Türk Evinin Mimarisi, Türkler Ansiklopedisi içinde (1. Baskı. Cilt 12). Ankara: Yeni Türkiye.

Cansever, T. (2010). Osmanlı Şehri (2. Baskı). İstanbul: Kültür Bakanlığı Yayıncılık.

Cerasi, M. (1999). Osmanlı Kenti (1. Baskı). İstanbul: YKY.

Çetiner, E. (2014). Bazı Örnekleriyle İmir Konutlarında Kapılar. (Yayımlanmamış Yüksek Lisans Tezi). Ege Üniversitesi Sosyal Bilimler Enstitüsü, İzmir.

Demirbağ, U. ve Urfalıoğlu, N. (2021). The Decoration in Traditional Houses Anatolian in 19th Century: The Example of Çankırı, History Studies, 13 (1), 265 - 283.

Diler, H. ve Erbil, Y. (2017, Mayıs). Geleneksel Burdur Evlerinin ve Süslemelerinin iç Mekân Kurgusunda İncelenmesi. 4. Ulusal Meslek Yüksekokulları Sosyal ve Teknik Bilimler Kongresinde Sunulan Bildiri, Burdur, Türkiye.

Eldem, S.H. (1954). Türk Evi Plan Tipleri (1. Baskı). İstanbul: iTÜ Mimarlık Fakültesi. 
Eldem, S.H. (1984). Türk Evi I (1. Baskı). İstanbul: Taç Vakfı.

Eldem, S.H. (1987). Türk Evi III (1. Baskı). İstanbul: Taç Vakfı.

Günay, R. (1999). Türk Ev Geleneği ve Safranbolu Evleri (2. Baskı). İstanbul: Yem.

Işık, Z. ve Yıldırım, K. (2002). Dekorasyonda Ince Yapı. Ankara: Gazi Üniversitesi Teknik Eğitim Fakültesi.

İşcan, N. (1979). Türk Süsleme Sanatı (1. Baskı). Eskişehir: Ülkü.

Kahraman, B. (1997). Geleneksel Türk Evi Odasında Ahşap Iç Mimari Elemanlar. (Yayımlanmamış Yüksek Lisans Tezi). Mimar Sinan Güzel Sanatlar Üniversitesi Fen Bilimleri Enstitüsü, İstanbul.

Kara, E. (__). İstanbul'da Pencere Önünde Kafes Örneği. https://www. erolkara.net/2019/02/cumbal-ve-kafes-pencereli-evler.html (Erişim Tarihi: 10 Mayıs 2021

Kılıç, E. (2010). Geleneksel Mardin Evlerine Ait Ahşap Kapıların Malzeme ve Yapım Tekniği Bakımından İncelenmesi. (Yayımlanmamış Yüksek Lisans Tezi). Gazi Üniversitesi Fen Bilimleri Enstitüsü, Ankara.

Kuban, D. (1995). Türk Hayatlı Evi (1. Baskı). İstanbul: Ziraat Bankası.

Küçükerman, Ö. (1985). Kendi Mekanının Arayışı lç̧inde Türk Evi (2. Baskı). İstanbul: Türkiye Turing ve Otomobil Kurumu.

Öztek, S. A. (2014). İstanbul'un En Eski Evi. https://restoret.wordpress. com/2014/07/04/istanbulun-en-eski-evi/ Erişim Tarihi: 20 Haziran 2018

Perker, Z. S. (2012, Nisan). Geleneksel Cumalıkızık Konutlarında Cephe Özellikleri ve Günümüzdeki Durum. 6. Ulusal Çatı ve Cephe Sempozyumunda Sunulan Bildiri, Bursa, Türkiye.

Pilehvarian, N. K. (__ (_) Mimarlık Tarihi Ders Notları, Yıldız Teknik Üniversitesi, İstanbul.

Sezgin, H. (2006). Yöresel Konu† Mimarisi ve Türkiye'deki Örnekleri Hakkında. Tasarım Kuram Dergisi, 3(4), 1-20.

Sözen M. (2001). Türklerde Ev Kültürü (1. Baskı). İstanbul: Doğan. 
Sözen, M. ve Eruzun C. (1992). Anadolu'da Ev ve Insan (1. Baskı). İstanbul: Creative \& Emlak Bankası.

Sözen, M. ve Tanyeli, U. (1992). Sanat Kavramları ve Terimler Sözlüğü (1. Baskı). İstanbul: Remzi.

Urfalıoğlu, N. (2010). Antalya, Isparta ve Burdur Evlerinde Cephe Biçimlenişi (1. Baskı). Antalya: Suna - Inan Kıraç Akdeniz Medeniyetleri Araştırma Enstitüsü.

Ünver, A. S. (1965). Türk Sanat Tarihinde Edirnekâri Lâke İşleri ve Sanatkârları. Vakıflar Dergisi, 6, 15-20.

Yılmaz, N. (2016). Ahşap Kapıların Büyüsü. http://lebriz.com/pages/lsd. aspx? lang=TR\&section ID = 12\&articleID=1337\&bhcp=1 Erişim Tarihi: 1 Temmuz 2019 